\title{
Metals and As content in sediments and Manila clam Ruditapes philippinarum in the Tagus estuary (Portugal): Impacts and risk for human consumption
}

\author{
Stefania Chiesa ${ }^{\mathrm{a}}$, Paula Chainho ${ }^{\mathrm{b}}$, Ângela Almeida ${ }^{\mathrm{a}}$, Etelvina Figueira ${ }^{\mathrm{a}}$, Amadeu M.V.M. Soares ${ }^{\mathrm{a}}$, \\ Rosa Freitas,
}

a Department of Biology, CESAM, University of Aveiro, Campus de Santiago, 3810-193 Aveiro, Portugal

${ }^{\mathrm{b}}$ MARE, Marine and Environmental Sciences Centre, Faculty of Sciences, Lisbon University, Campo Grande, 1749-016 Lisbon, Portugal

\section{A R T I C L E I N F O}

\section{Keywords:}

Manila clam

Tagus estuary

Metals and As content

Health risk

Biomarkers

\begin{abstract}
A B S T R A C T
The Manila clam is emerging as a relevant species for the Portuguese market. The present work was conducted in the Tagus estuary to evaluate 1) the metals and As content in the sediments of the Tagus estuary, especially on those areas subjected to Manila clam harvesting 2) the metals and As content in clams, and the risk associated with their consumption 3) the physiological and biochemical responses of the clam to metals and As contamination, and its possible role as a pollution bioindicator in the estuarine environment. The most contaminated sediments were identified nearby industrial areas, nevertheless clams collected in low contaminated areas showed high metals and As concentrations. The condition index, glycogen content, membrane oxidative damage, biotransformation enzymes and metallothioneins showed consistent responses to metals and As content in clams. Results emphasize the need for the development of a management plan for the species exploitation in the Tagus estuary.
\end{abstract}

\section{Introduction}

Among coastal ecosystems, estuaries are considered highly productive areas, although deeply impacted by anthropogenic pressure (Covelli et al., 2012). They represent complex and dynamic aquatic environments, frequently exploited for fisheries, aquaculture, industries, transport and recreational activities (Lei et al., 2016). Estuaries worldwide are also impacted by discharges from urban sites, since pollutants are transported by the rivers and then into the sea through estuaries (Mitchell et al., 1999). As a consequence, these environments are constantly exposed to a wide variety of pollutants, as metals and metalloids (Hoffman et al., 2002), organic (Cardoso et al., 2016) and new emerging contaminants, such as pharmaceuticals (Heberer, 2002) and micro plastics (Zhao et al., 2015).

Metals and metalloids have demonstrated to be hazardous pollutants, due to their persistency, toxicity and bioaccumulative characteristics (Du Laing, 2011; Velez et al., 2015a). Considering that sediments of coastal ecosystems can act as a sink for metals and metalloids, the benthic fauna, closely in contact with the sediments, is particularly vulnerable to their contamination (Elliott and Quintino, 2007). Metals and metalloids are readily bioaccumulated by benthic fauna, including bivalves (Freitas et al., 2012; Velez et al., 2015a; de Oliveira et al., 2016; Gao et al., 2016; Vazquez-Luis et al., 2016) and polychaetes (Dean, 2008; Freitas et al., 2012), inducing toxic effects.

Metals and metalloids are considered typical environmental pollutants with prooxidant effects, due to their potential to induce the intracellular formation of reactive oxygen species (ROS) (Regoli and Giuliani, 2014). In fact, biochemical markers, including oxidative stress markers, became popular tools for detecting early toxic effects in aquatic organisms caused by these inorganic elements (e.g. Monserrat et al., 2007; Matozzo et al., 2012; Moschino et al., 2012; Velez et al., 2015b). The comparison between biochemical performance obtained from the same species in different environments will allow to assess the toxic impacts induced by different pollution types and/or levels and the effectiveness of the biological responses to specific environmental conditions (Chandurvelan et al., 2015; Velez et al., 2016a).

Bivalves have been recognized as appropriate bioindicator and/or sentinel species of environmental quality in aquatic systems (Cajaraville et al., 2000), not only due to their filter feeding behavior and benthic ecology (for a complete list of references, see Velez et al., 2016a) but also due to their commercial importance as seafood. Among bivalve species, the Manila (Asari) clam Ruditapes philippinarum (Adams \& Reeve, 1850) is gaining increasing attention due to its wide geographic distribution and its ecological and economic relevance (Moschino et al., 2012). As a bivalve, the Manila clam presents high ability to accumulate elements in its tissues, with known capacities as bioindicator of

\footnotetext{
* Corresponding author.

E-mail address: rosafreitas@ua.pt (R. Freitas).
} 


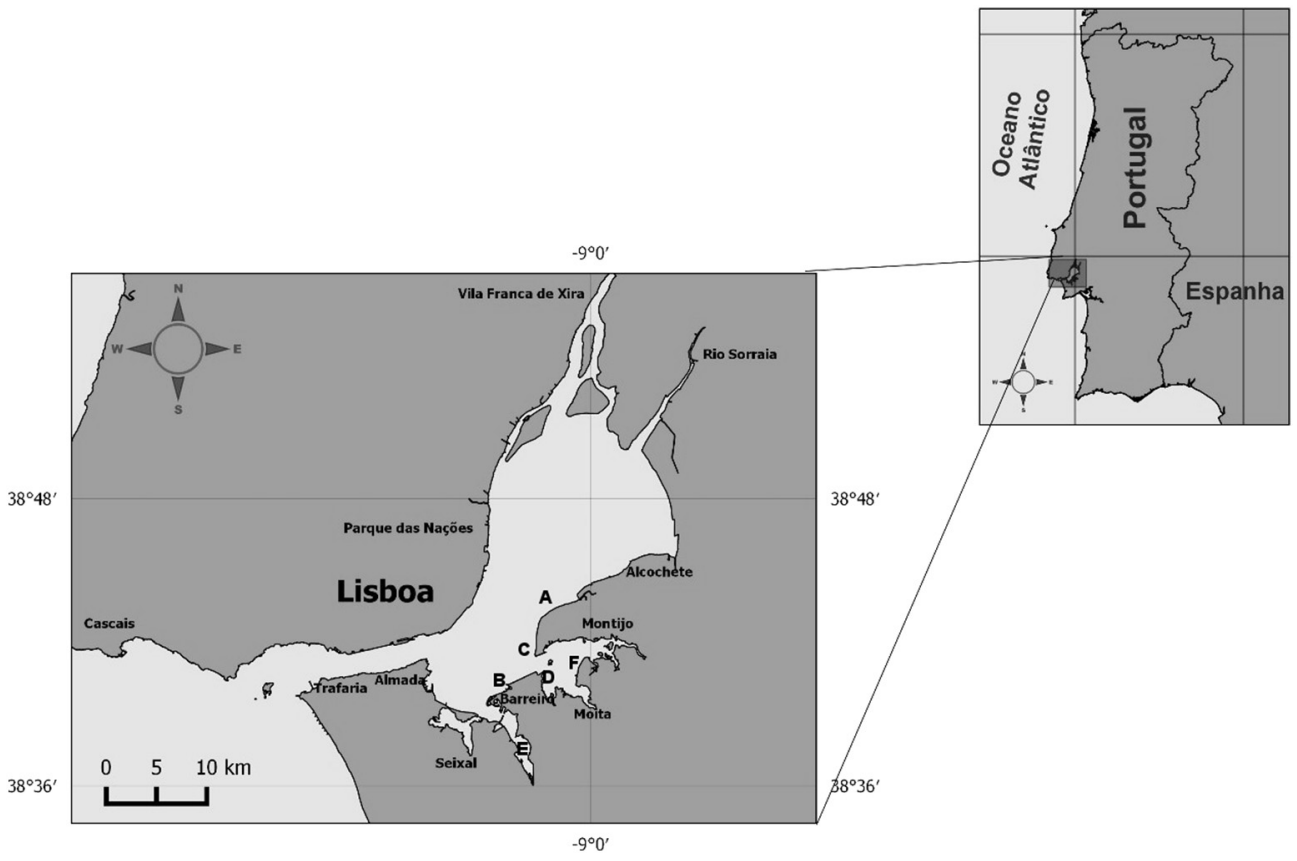

Fig. 1. Six sampling areas in the Tagus estuary (A-F).

elements pollution in estuarine environments (Sfriso et al., 2008; Matozzo et al., 2012; Moschino et al., 2012; Yang et al., 2013; Velez et al., 2015a,b). Its worldwide distribution is strictly connected to its economic relevance for fisheries and aquaculture: originally distributed in the Indo-Pacific region, specifically in Japan, Korea and China (Gosling, 2003), Manila clam was introduced into the west coast of North America, Atlantic (Portugal, France, Spain, Ireland, England) and Mediterranean European coasts (France, Italy) (Gosling, 2003). As for Portugal, the Manila clam was firstly detected in 1984 in Ria Formosa (Algarve) (Ruano and Sobral, 2000) and, since then, established populations have been reported in estuarine systems all over the country including in the Óbidos lagoon (Velez et al., 2015b), Albufeira lagoon (Gaspar, 2010), Ria de Aveiro (e.g. Figueira et al., 2012), the Sado estuary (Gaspar, 2010), and the Tagus estuary (Gaspar, 2010; Chainho et al., 2015). Today this species represents one of the most important commercial bivalve, with the highest economic value among aquaculture shellfish products (FAO, 2013). A special concern regarding the occurrence of Manila clam in the Tagus estuary is its wider distribution and increasing abundance in recent years (Ramajal et al., 2016).

The occurrence of intensive Manila clam fishing - especially with mechanical dredges - can have negative effects on environments, particularly concerning impacts on benthic communities, sediment resuspension and increase of water turbidity (Pranovi et al., 2003; Pranovi et al., 2004). These effects have been already observed in Venice Lagoon, where intense Manila clam collection has been carried out for $>20$ years, with dramatic effects on the lagoon environment, followed by a collapse of the clam production (see Boscolo Brusà et al., 2013 for a complete list of reference). Manila clam fishing in the Tagus Estuary is lacking a specific regulation, and many of illegal harvesters are actually involved in its collection and commerce (Ramajal et al., 2016). Moreover, the occurrence of illegal fishing can determinate a serious risk for human consumption, due to clam collection in microbiology or chemically polluted areas. It is well known that elements contamination in edible bivalves can determinate bioaccumulation in the trophic chain, especially in human consumers (Figueira et al., 2011) with consequent poisoning effects (Santos et al., 2014).

Taking into account the intense harvesting and commercial exploitation of Manila clam currently ongoing in the Tagus estuary, and the scarce informations regarding the environmental characterization of the exploited areas in terms of metals and As pollution, there is an urgent need to investigate the contamination levels in clams at the harvesting areas, and to reveal their use as bioindicator species and role as source of pollutants along the ecosystems trophic chain.

In this way, the aims of the present work were 1) to evaluate sediments contamination in the Tagus estuary, namely in terms of metals and As, within the areas used for Manila clam harvesting; 2) to quantify the metals and As content in the Manila clam, and the human health risks associated with its consumption; 3 ) to assess the physiological and biochemical performance of the species to different elements and concentration levels, and its possible role as a bioindicator of pollution in the Tagus estuary.

\section{Materials and methods}

\subsection{Study area}

The Tagus estuary is one of the largest estuaries in Europe, covering an area of $320 \mathrm{~km}^{2}: 40 \%$ of the estuary is composed of intertidal mudflats, and its eastern and southern areas contain extensive areas of salt marshes (Caçador et al., 1996). The main source of freshwater onto the Tagus estuary is the Tagus river, draining water from a total area of $86,629 \mathrm{~km}^{2}$, and representing the second most important hydrological basin in the Iberian Peninsula (Duarte and Caçador, 2012) in terms of dimensions. The Tagus estuary also represents a major seaport, hosting both commercial and fishing activities (Chainho et al., 2014; Duarte et al., 2014). This system used to be adversely affected by untreated urban sewage discharges, together with industry (chemicals, petrochemicals, metallurgic, shipyard and repair and cement manufacture) and agriculture-fertilizers and pesticides (Duarte et al., 2014). Although the treatment of both industrial and urban effluents has been improved in the latest decades (Chainho et al., 2014; Duarte and Caçador, 2012), this area represents a sink of historically accumulated metals and metalloids (Caçador et al., 1996). Previous studies identified high levels of zinc in the surface sediments (Vinagre et al., 2008), chromium, nickel, cobalt and also mercury (Vale et al., 2008; Mil-Homens et al., 2014). Moreover, elements like cadmium, copper, lead and zinc exhibited enhanced aluminium ratios mirroring the presence of anthropogenic local inputs associated with harbour, urban and industrial activities (Mil-Homens et al., 2014).

Six different areas located in the Southern branch of the Tagus 
estuary were selected based on i) the high abundance of the Manila clam, according to recent data on the species distribution (Carvalho, 2016), ii) previous data on element contamination levels (Chainho et al., 2014) and iii) different sediment grain size (Calvário, 2001) (Fig. 1).

\subsection{Sampling procedures}

Sampling surveys were carried out in April-May 2015. Six areas were selected for analyses: A - Samouco, B - Outer Barreiro Bay, C Airbase, D - Outer Montijo Bay, E - Inner Barreiro Bay, F - Inner Montijo Bay. For each of the six investigated areas, three sampling sites were selected, totalizing eighteen sampling locations.

Environmental parameters of water and sediments $(\mathrm{pH}$, salinity, temperature and redox potential) were measured with specific probes at each sampling site. Twenty five clams ( $R$. philippinarum) with similar size were collected at each site for size measurements, bioaccumulation and biochemical analyses. Moreover, estuarine sediments were collected at each sampling site, for subsequent sediment grain size analysis, total organic matter (TOM) content determination, and quantification of metals and As content.

After sampling, specimens and sediments were transported on ice $\left(0{ }^{\circ} \mathrm{C}\right)$ to the laboratory.

From each sampling site, five individuals were measured (shell length and width expressed in $\mathrm{cm}$ ), weighted ( $\mathrm{g}$ ), and used to determine the condition index (C.I.).

The remaining organisms were preserved at $-80{ }^{\circ} \mathrm{C}$ until analysis.

For metals and As quantification and biochemical analyses organisms (whole soft tissues) were individually pulverized with liquid nitrogen. Five specimens from each sampling site $(5 \times 18=90$ total specimens) were used for biochemical analyses, and three of these specimens from each sampling site $(3 \times 18=60$ total specimens $)$ were also used for metals and As quantifications.

\subsection{Laboratory analysis}

\subsubsection{Sediment grain size and organic matter content determination}

Sediment grain-size was analyzed by wet and dry sieving following the procedure described by Quintino et al. (1989). The median value, P50, was calculated and expressed in phi $(\Phi)$ units, corresponding to the diameter that has half the grains finer and half coarser (dry weight). The median and the percent content of fines were used to classify the sediment, according to the Wentworth scale. Clean sediments were considered those with silt and clay fraction among $0 \%-5 \%$, silty when the fraction resulted among 5\%-25\% and very silty among 5\%-50\% (Doeglas, 1968; Larsonneur, 1977). Samples with $>50 \%$ fines content were classified as muddy.

The TOM content was determined according to Byers et al. (1978), corresponding to the percentage of weight loss in $1 \mathrm{~g}$ of dried sediment, after combustion at $450{ }^{\circ} \mathrm{C}$ during $5 \mathrm{~h}$.

\subsubsection{Metals and As quantification in sediments and clams}

The concentration of seven elements (chromium, Cr; nickel, Ni; zinc, $\mathrm{Zn}$; arsenic, As; cadmium, Cd; lead, Pb; mercury, $\mathrm{Hg}$ ) was measured in organisms whole soft tissues and sediments (bulk samples). For metals and As quantification in sediments, $2 \mathrm{~g}$ of homogenized air dried sediment was digested overnight ( $\pm 18 \mathrm{~h}$ ) in Teflon bombs, at $115^{\circ} \mathrm{C}$ with $10 \mathrm{~mL}$ of aqua regia solution $\left(1: 3 \mathrm{HNO}_{3}: \mathrm{HCl}\right)$. To prevent the loss of elements by volatilization, chambers were only opened when completely cooled. The cooled digest was made up to $50 \mathrm{~mL}$ with distilled water. In order to obtain the total concentration of metals and As present in clams, organisms (soft tissues) were transferred to Teflon bombs. The biological samples were digested overnight $( \pm 18 \mathrm{~h})$ at $115{ }^{\circ} \mathrm{C}$ with $2 \mathrm{~mL}$ of the same aqua regia solution. The cooled digest was made up to $15 \mathrm{~mL}$ with distilled water.

All the metals and As quantifications were done by ICP-MS
(Inductively Coupled Plasma-Mass Spectrometry) in a certified laboratory at the University of Aveiro. Regarding the quality controls, the calibration was made with successive dilutions of multi-element standard ICP 71A from IV (Inorganic Venture, Christians-burg, VA, USA). The fitness of the calibration curve was checked with CRM NIST 1643e. The whole procedure was verified with standard certificated reference materials (CRM): MESS-3 (for sediments) and TORT-2 (for clams soft tissues), both from NRCC (National Research Council of Canada). The values obtained for the whole of the CRM analysis ranged from $80 \%$ to $110 \%$. All samples below this accuracy level were rejected and the analysis repeated.

As already described by Velez et al. (2015b) the concentration of metals and As in clams was expressed in $\mathrm{mg} \mathrm{kg}^{-1}$ fresh weight (FW), to compare with maximum permissible limits expressed in $\mathrm{mg} \mathrm{kg}^{-1} \mathrm{FW}$, but also in dry weight (DW) according to Ponsero et al. (2009), to make comparisons with literature data and to allow the determination of the Biota-Sediment Accumulation Factor (BSAF). The concentration of metals and As in sediments was expressed in $\mathrm{mg} \mathrm{kg}^{-1}$ of dry weight (DW), since the sediments were previously dried during $48 \mathrm{~h}$ at $25^{\circ} \mathrm{C}$ to allow the comparison between the present data and sediment quality guideline values, those related to the threshold effect, specifically TEL Threshold Effect Level (MacDonald et al., 1996) and ERL - Effects Range Low (Long and Morgan, 1990); plus, those referred to the Midrange effect, specifically Probable Effects Level - PEL (MacDonald et al., 1996) and Effects Range Median - ERM (Long and Morgan, 1990).

The Biota-Sediment Accumulation Factor (BSAF) was determined dividing the total concentration of a given element in the organism (dry weight) by the concentration of that element in the sediment (dry weight) (Cheng et al., 2013).

As for the bioaccumulation levels, for each of the six investigated areas, the amount of clams that a $70 \mathrm{~kg}$ adult need to consume in one week to exceed Provisional Tolerable Weekly Intake (PTWI) was determined. This value was obtained by dividing the PTWI of a $70 \mathrm{~kg}$ adult by the concentration of a given element in clams.

\subsubsection{Biological parameters}

The determination of the condition index (C.I.) provides an indication of the general physiological status of the animals (Matozzo et al., 2012). Clams soft tissues were carefully separated from shells and dried in an oven at $60{ }^{\circ} \mathrm{C}$ for $48 \mathrm{~h}$, and then shells and soft tissues were weighed. The C.I. values were expressed as the ratio between the dry weight of soft tissues and the dry weight of shell $\times 100$ times (Matozzo et al., 2012).

Biochemical analyses were performed using $0.5 \mathrm{~g}$ of soft tissues in each individual ( 5 individuals per site $/ 3 \times 5=15$ individuals per area). Samples were extracted with a specific buffer for each biochemical parameter and centrifuged $(10,000 \mathrm{~g})$ for $15 \mathrm{~min}$ at $4{ }^{\circ} \mathrm{C}$. Supernatants were stored at $-20^{\circ} \mathrm{C}$ or used immediately. A Thermo Scientific Multiskan GO UV/Vis Microplate Spectrophotometer was used for quantifications.

The following biochemical parameters were measured: Glycogen (GLY) and protein (PROT) concentrations to obtain information on clams energy reserves; lipid peroxidation (LPO) an indicator of cellular damages; superoxide dismutase (SOD), catalase (CAT), total glutathione (GSHt) and glutathione $S$-transferase (GSTs), indicators of antioxidant and biotransformation responses. Also metallothioneins (MTs) were investigated as specific biomarkers of metal contamination.

GLY content was determined following the procedure described by Dubois et al. (1956) by the phenol-sulphuric acid method and the results were expressed as $\mathrm{mg} / \mathrm{g}$ of fresh weigh (FW).

PROT content was determined according to Robinson and Hogden (1940) with the Biuret method, using bovine serum albumin (BSA) as standard $(0-40 \mathrm{mg} / \mathrm{mL})$. The results were expressed in $\mathrm{mg} / \mathrm{g}$ of FW.

LPO quantification was based on the reaction of LPO by-products, such as malondialdehyde (MDA), with 2-thiobarbituric acid (TBA), following the Buege and Aust (1978) protocol. The results were 
Table 1

Environmental parameters of the sampling areas.

\begin{tabular}{lllll}
\hline Area & Water salinity (\%o) & Sediment $\mathrm{pH}$ & Sediment $\mathrm{T}\left({ }^{\circ} \mathrm{C}\right)$ & Sediment Eh $(\mathrm{mV})$ \\
\hline A & 24 & 7.54 & 18 & -43 \\
B & 31 & 7.41 & 22.6 & -34 \\
C & 30 & 7.48 & 22.1 & -38 \\
D & 30 & 7.64 & 17.6 & -44 \\
E & 30 & 7.16 & 21.6 & -23 \\
F & 40 & 7.44 & 21.3 & -35 \\
\hline
\end{tabular}

Water salinity (\%), sediment $\mathrm{pH}$, sediment temperature $\left({ }^{\circ} \mathrm{C}\right)$, sediment Eh $(\mathrm{mV})$ collected at each sampling area in the Tagus estuary.

expressed as nmol of MDA equivalents/g of FW.

GSHt content was calculated as the sum of reduced (GSH) and oxidized (GSSG) content, determined according to the protocol by Rahman et al. (2007), using reduced and oxidized glutathione as standard $(0-60 \mu \mathrm{mol} / \mathrm{L})$, and results were expressed as $\mu \mathrm{mol} / \mathrm{g}$ of $\mathrm{FW}$.

SOD activity was quantified by the method described by Beauchamp and Fridovich (1971), with slight modifications (Freitas et al., 2012). SOD standards were used $(0.25-60 \mathrm{U} / \mathrm{ml})$ and its activity was expressed as $\mathrm{U} / \mathrm{g}$ of FW. One unit (U) of enzyme activity corresponds to a reduction of $50 \%$ of nitro blue tetrazolium (NBT).

CAT activity was measured according to Johansson and Borg (1988). Formaldehyde standards $(0-150 \mu \mathrm{M})$ were used as standard. The absorbance was read at $540 \mathrm{~nm}$. CAT activity was expressed in $\mathrm{U} / \mathrm{g}$ of FW. One unit (U) of enzyme activity represents the formation of $1.0 \mathrm{nmol}$ formaldehyde/min.

GSTs activity was determined following the method described by Habig et al. (1974). For the enzyme activity quantification a time interval was selected $(5 \mathrm{~min}$ ) during which the activity was linear. The activity of GSTs was determined using extinction coefficient of $9.6 \mathrm{mM}^{-1} \mathrm{~cm}^{-1}$ for CDNB. The absorbance was read at $340 \mathrm{~nm}$. Results were expressed as $\mathrm{U} / \mathrm{g}$ of $\mathrm{FW}$; one unit of enzyme (U) corresponds to the amount of enzyme that caused the formation of $1 \mu \mathrm{mol}$ of dinitrophenyl thioether/min.

Protocols herein used are also fully described in details in previous papers (Velez et al., 2014, 2015b).

Metallothioneins separation was carried out by SDS-PAGE, carried out in $4-20 \%$ polyacrylamide (Mini-PROTEAN TGX Bio-Rad, MiniPROTEAN ${ }^{\circledR}$ ), according the procedure described by Laemmli (1970). Gels were stained with Coomassie Brilliant Blue R-250 and screened in a Densitometer apparatus (Bio-Rad-Model GS 710). Molecular mass and relative protein amount corresponding to each band were compared with a protein standard (NZY Color Protein Marker II-NZY Tech Genes and Enzymes). Concentration of proteins was calculated using Quantity One program software (Bio-Rad) and expressed as $\mu \mathrm{g} / \mathrm{g}$. Confirmation of MT proteins was achieved comparing bands with those already described for $R$. philippinarum in previous studies (see Velez et al., 2016b).

\subsection{Statistical analyses}

Statistical differences on sediment characteristics (fines content and TOM), the total concentration of metals and As in sediments and clams, the total BSAF values, and all physiological and biochemical parameters among different areas were assessed by hypothesis testing using the PERMANOVA routine (permutational multivariate analysis of variance), following the calculation of Euclidean distance matrices among samples. The t-statistic in the pairwise comparisons was evaluated in terms of significance among different areas. The main null hypotheses tested were: a) there are no significant differences on sediment characteristics (TOM and fines content) and sediment contamination (each metal and As content; total metals + As content) among areas; b) there are no significant differences on metals and As accumulated by clams (each metal and As concentration; total metals + As concentration) among areas; c) there are no significant differences on clams physiological and biochemical parameters among areas. A significance level of $p<0.05$ was considered and significant differences were identified in figures and tables using different letters. Statistical analyses were conducted using PRIMERv6 ${ }^{\circledR}$ (Plymouth Marine Laboratory) (Anderson et al., 2008).

STATISTICA software (version 10) was used to infer the correlations among environmental parameters (fines and TOM content), metals and As content in sediments, metals and As content in clams, physiological and biochemical responses by calculating the Pearson coefficients at significant $(p<0.05)$ and highly significant $(p<0.01)$.

Finally, a Principal Component Analysis (PCA) was performed by CANOCO (version 5.0) to visualize the multivariate patterns of physiological and biochemical status of the Manila clam in response to metals and As content in clams.

\section{Results}

\subsection{Sediments}

\subsubsection{Physico-chemical characteristics of the investigated areas}

Water salinity ranged from 24 (area A) to 40 (area F); sediment pH varied slightly among the study areas, ranging between 7.16 (area E) and 7.64 (area D) and sediment temperature ranged from $17.6^{\circ} \mathrm{C}$ (area D) to $22.6{ }^{\circ} \mathrm{C}$ (area B). Sediment Eh ranged from $-23 \mathrm{mV}$ (area E) to $-44 \mathrm{mV}$ (area D) (see Table 1 for details).

The sediment grain size analysis showed that the areas with higher percentage of fine sediments - B and E - also presented higher organic matter content. In terms of fines content, these two areas showed significantly higher values than areas $\mathrm{C}$ and $\mathrm{D}$ (for area $\mathrm{B}$ ), as well as than areas $\mathrm{A}$ and $\mathrm{F}$ (for area E) (Fig. 2A). As for TOM content, areas B and E showed significantly higher values than area D (for area B), as well as all other investigated areas, in case of area E (Fig. 2B).

In detail, the granulometric analyses results showed that for the area A the median value corresponded to $2.6 \Phi$, and the three replicate sites were classified as very fine/fine/medium silty sand. Area B showed a median value corresponding to $3.3 \Phi$, and all sites were classified as mud and medium silty sand; as for the area $\mathrm{C}$, median value corresponded to $1.7 \Phi$, with the all three replicate sites classified as medium silty sand. The median value for the area D corresponded to $2.1 \Phi$, and all sites were classified as medium silty and fine silty sand. As for the area E, median value was exceeding $4 \Phi$, and all sites were classified as muddy. Finally, area F median value corresponded to $1.8 \Phi$, and all sites were classified as medium silty sand.

\subsubsection{Metals and As content in the sediments}

Sediment data are shown in Fig. 2C for total metal and As content and in Table 2 for single elements ( $\mathrm{Cr}, \mathrm{Ni}, \mathrm{Zn}, \mathrm{As}, \mathrm{Cd}, \mathrm{Pb}, \mathrm{Hg}$ ). The total metal and As content in sediments revealed higher values in areas B and E (258 and $264 \mathrm{mg} \mathrm{kg}^{-1}$ DW respectively) with significant statistical differences between these two areas and the least contaminated areas A and C (Fig. 2C). The total concentration of metal and As in these two areas was 61.5 and $79.5 \mathrm{mg} \mathrm{kg}^{-1} \mathrm{DW}$, respectively.

Considering the single elements, $\mathrm{Zn}$ was the most abundant element in most areas, ranging from 30.3 to $122 \mathrm{mg} \mathrm{kg}^{-1} \mathrm{DW}$, followed by $\mathrm{Pb}$

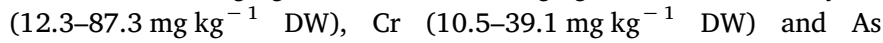
(4.82-24.8 $\mathrm{mg} \mathrm{kg}^{-1} \mathrm{DW}$ ) (Table 2). The least abundant elements were $\mathrm{Ni}\left(2.15-6.60 \mathrm{mg} \mathrm{kg}^{-1} \mathrm{DW}\right), \mathrm{Hg}\left(0.09-0.97 \mathrm{mg} \mathrm{kg}^{-1} \mathrm{DW}\right)$, and $\mathrm{Cd}$ (0.05-0.49 $\left.\mathrm{mg} \mathrm{kg}^{-1} \mathrm{DW}\right)$. Areas B and E presented the highest concentrations for almost of the analyzed elements (Table 2) with significant statistical differences occurring among the least contaminated areas $\mathrm{A}, \mathrm{C}$ and the most contaminated one $\mathrm{E}$ (see Table 2).

$\mathrm{Cr}, \mathrm{Ni}, \mathrm{Zn}$ and $\mathrm{Cd}$ presented concentrations lower than the corresponding TEL (Threshold Effect Level), ERL (Effects Range Low), PEL (Probable Effects Levels) and ERM (Effects Range Median), whilst As, $\mathrm{Pb}$ and $\mathrm{Hg}$ exceed the TEL and ERL limits in four of the six investigated 

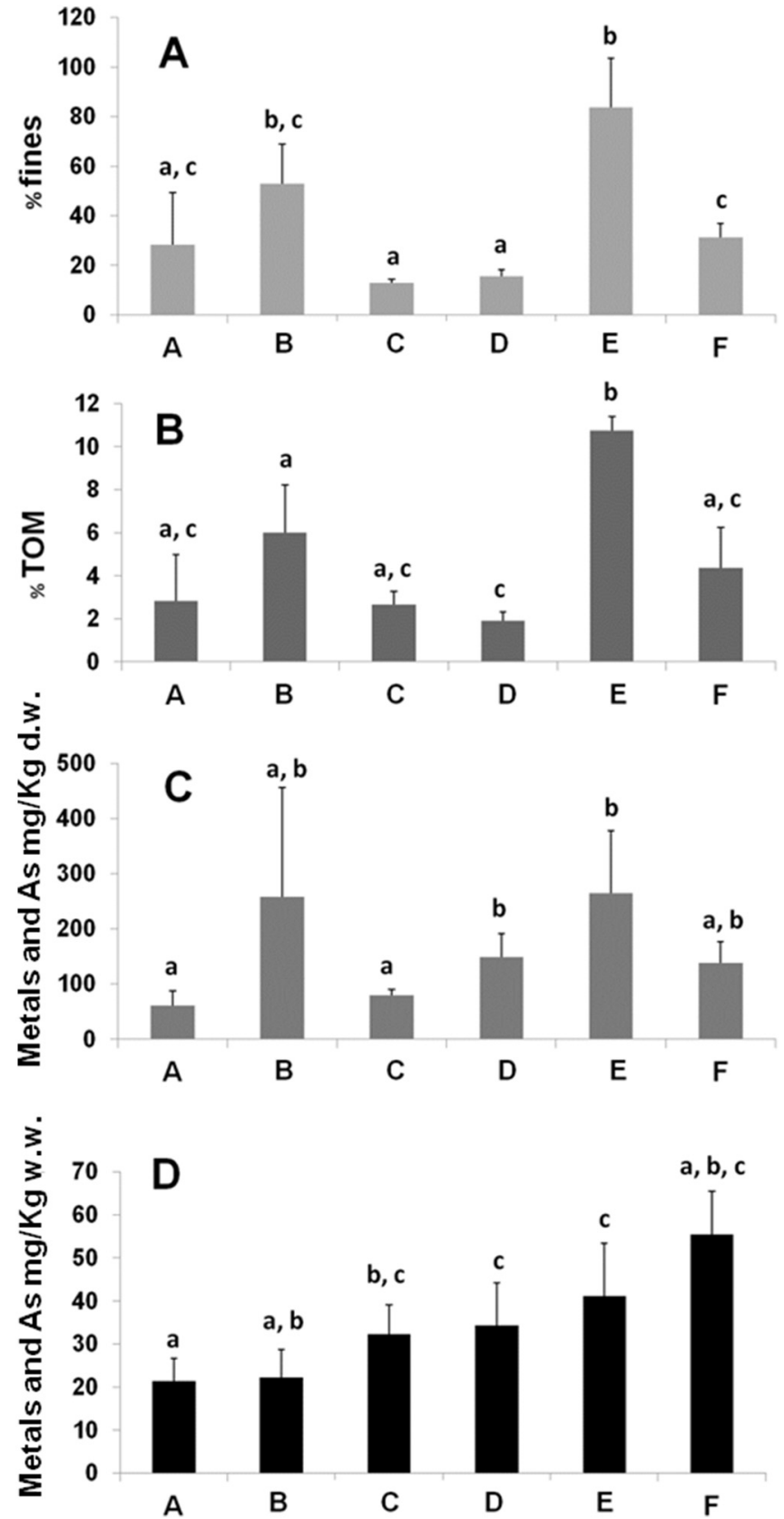

Fig. 2. Fine particles, TOM, metals and As content in sediments and clams. Percentage of fine particles (A) and TOM content (B); total metals and As content in sediments ( $\mathrm{mg} \mathrm{kg}{ }^{-1}$ dry weight) (C) and total metals and As content in clams ( $\mathrm{mg} \mathrm{kg}^{-1}$ wet weight) (D) for each analyzed area of the Tagus estuary. Significant differences $(p<0.05)$ among areas are represented with distinct letters $(a-c)$. Data from the different areas are presented following the bioaccumulation gradient in clams.

areas (B, D, E, F) (Table 2). In particular, for $\mathrm{Hg}$ sediments from area D exceed all the $\mathrm{Hg}$ limits, including PEL and ERM.

\subsection{Clams}

\subsubsection{Metals and As content in R. philippinarum clams}

Clams data are shown in Fig. 2D and Table 3. An increasing concentration of metals and As was observed from area A to area F (see Fig. 2D). The highest values for the total concentration of metals and As were detected in clams collected at areas $\mathrm{E}$ and F (respectively 41.2 and $55.4 \mathrm{mg} \mathrm{kg}^{-1} \mathrm{FW}$ ), whilst the lowest values were observed in clams from areas A and B (respectively 21.4 and $22.2 \mathrm{mg} \mathrm{kg}^{-1}$ FW) (Fig. 2D), with significant statistical differences between areas A and E (Fig. 2D).
As observed for the sediments, for the majority of the investigated areas $\mathrm{Zn}$ was the most abundant element also in clams, ranging from 14.2 to $30.1 \mathrm{mg} \mathrm{kg}^{-1} \mathrm{FW}$, followed by As (2.42-21.8 $\left.\mathrm{mg} \mathrm{kg}^{-1} \mathrm{FW}\right), \mathrm{Cr}$

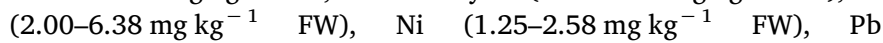
$\left(0.45-2.78 \mathrm{mg} \mathrm{kg}^{-1} \mathrm{FW}\right), \mathrm{Hg} \quad\left(0.02-0.13 \mathrm{mg} \mathrm{kg}^{-1} \mathrm{FW}\right)$ and $\mathrm{Cd}$ (0.06-0.10 $\mathrm{mg} \mathrm{kg}^{-1} \mathrm{FW}$ ) (Table 3).

Generally, for most of the elements, significant statistical differences were observed among the least contaminated clams (collected from areas A, B, D) and the most contaminated ones (collected from areas C, E, F). However, for Cd no significant differences were observed among clams collected from different areas.

Results for the Biota-Sediment Accumulation Factor (BSAF) are shown in Table 4.

The highest values of total BSAF were observed in clams from areas $\mathrm{A}, \mathrm{C}$ and $\mathrm{F}$ and the lowest values were recorded in clams from areas B and $\mathrm{E}$, although no statistical differences were found among areas.

The highest BSAF values for single elements were observed for As (especially in area F) and for $\mathrm{Cd}, \mathrm{Ni}, \mathrm{Hg}$ and $\mathrm{Cr}$ (areas A and C). Lower BSAF values were observed for $\mathrm{Pb}$, with the exception of clams from area C. Significant statistical differences were generally observed for most elements between clams from area $\mathrm{C}$ and those from areas $\mathrm{B}$ and $\mathrm{E}$.

It must be emphasized that the highest BSAF values for almost all elements were observed in clams from the least contaminated areas (especially A and C), whilst the lowest BSAF values were observed in clams from the most contaminated areas (B and $\mathrm{E}$ ).

\subsubsection{Risk assessment of clams consumption}

Considering the maximum permissible limits defined by international organizations (EFSA, European Food Safe Authority; USFDA, United States Food and Drug Administration; FSANZ, Food Standards Australia and New Zealand; JECFA, Joint FAO/WHO Expert Committee on Food Additives) for the analyzed elements, clams herein analyzed did not exceed the limits for $\mathrm{Cr}, \mathrm{Ni}, \mathrm{Cd}$ and $\mathrm{Hg}$ (see Tables 3 and 5). However, clams collected in areas C, D and E exceeded the limits for the $\mathrm{Pb}$ concentrations and As concentrations found in all of the six investigated areas exceeded the FSANZ standard values (Tables 3 and 5).

The amount of clams soft tissues that a $70 \mathrm{~kg}$ adult needs to consume in one week to exceed the PTWI is shown in Table 5. The results based on total As content indicated higher health risks concerning the contamination by As in all investigated areas, since $0.05-0.43 \mathrm{~kg}$ (FW) of clams consumed in one week are sufficient to exceed the PTWI. The risk is particularly high at area F, where clams accumulated the highest amount of total As. However, FSANZ standard values, JECFA and FSANZ PTWI values are referred only to the inorganic As content in seafood, whilst the results herein presented are referred to total As content in clams. Moreover, risk levels were also high for $\mathrm{Pb}$ and $\mathrm{Ni}$ : whilst $0.63 \mathrm{~kg}$ FW consumed per week would be enough to exceed the $\mathrm{PTWI}$ for $\mathrm{Pb}$ at area $\mathrm{C}, 0.95 \mathrm{~kg}$ of clams per week would exceed the PTWI limits for Ni at area F.

\subsubsection{Biological responses}

The mean length of specimens collected at the six investigated areas ranged between $3.77 \mathrm{~cm}$ and $4.10 \mathrm{~cm}$, with the mean width ranging between $2.84 \mathrm{~cm}$ and $3.15 \mathrm{~cm}$ and the mean dry weight between $0.54 \mathrm{~g}$ and $0.81 \mathrm{~g}$ (Supplementary Table 1).

The highest values of the condition index (C.I.) were recorded for clams collected at areas $\mathrm{E}$ and $\mathrm{F}$ (Fig. 3A), those characterized by higher metals and As concentrations in clams. Contrarily, the lowest C.I. values were observed in areas $\mathrm{C}$ and $\mathrm{D}$, which are characterized by medium levels of metals and As concentration. Significant statistical differences were observed among area $\mathrm{F}$ and areas $\mathrm{C}$ and D (Fig. 3A).

GLY and PROT content results are presented in Fig. 3B and C, respectively. The results obtained showed that the GLY content is higher in clams with higher metal and As concentration, those collected in areas $\mathrm{E}$ and $\mathrm{F}$, with significant statistical differences among clams characterized by the lowest (B, C) and the highest GLY content (E) 
Table 2

Metals and As content in the sediments of the Tagus estuary.

\begin{tabular}{|c|c|c|c|c|c|c|c|}
\hline Area & $\mathrm{Cr}$ & $\mathrm{Ni}$ & $\mathrm{Zn}$ & As & $\mathrm{Cd}$ & $\mathrm{Pb}$ & $\mathrm{Hg}$ \\
\hline A & $11.0 \pm 5.80^{\mathrm{a}}$ & $2.88 \pm 1.53^{\mathrm{a}, \mathrm{b}}$ & $30.3 \pm 12.1^{\mathrm{a}}$ & $4.82 \pm 2.43^{\mathrm{a}, \mathrm{b}}$ & $0.05 \pm 0.03^{\mathrm{a}}$ & $12.3 \pm 4.55^{\mathrm{a}}$ & $0.09 \pm 0.05^{\mathrm{a}}$ \\
\hline B & $18.1 \pm 5.80^{\mathrm{a}, \mathrm{b}}$ & $4.71 \pm 1.17^{\mathrm{b}, \mathrm{c}}$ & $122 \pm 83.4^{\mathrm{a}, \mathrm{b}}$ & $24.8 \pm 22.0^{\mathrm{a}, \mathrm{b}}$ & $0.49 \pm 0.33^{\mathrm{a}, \mathrm{b}}$ & $87.3 \pm 85.9^{a, b}$ & $0.62 \pm 0.46^{\mathrm{a}, \mathrm{b}}$ \\
\hline C & $10.5 \pm 2.50^{\mathrm{a}}$ & $3.02 \pm 0.52^{\mathrm{a}, \mathrm{b}}$ & $44.1 \pm 4.89^{\mathrm{a}, \mathrm{b}}$ & $5.17 \pm 0.90^{\mathrm{a}}$ & $0.08 \pm 0.01^{\mathrm{a}}$ & $16.5 \pm 2.48^{\mathrm{a}}$ & $0.12 \pm 0.01^{\mathrm{a}, \mathrm{b}}$ \\
\hline $\mathrm{D}$ & $10.9 \pm 2.60^{\mathrm{a}}$ & $2.15 \pm 0.65^{\mathrm{a}}$ & $74.9 \pm 25.4^{\mathrm{b}}$ & $12.4 \pm 4.13^{\mathrm{b}}$ & $0.17 \pm 0.02^{\mathrm{b}}$ & $47.0 \pm 15.8^{b}$ & $0.97 \pm 0.66^{\mathrm{a}, \mathrm{b}}$ \\
\hline $\mathrm{E}$ & $39.1 \pm 16.0^{\mathrm{b}}$ & $6.60 \pm 1.67^{c}$ & $119 \pm 48.4^{\mathrm{b}}$ & $20.6 \pm 11.8^{\mathrm{a}, \mathrm{b}}$ & $0.44 \pm 0.19^{b}$ & $77.7 \pm 40.7^{\mathrm{a}, \mathrm{b}}$ & $0.60 \pm 0.30^{\mathrm{b}}$ \\
\hline $\mathrm{F}$ & $18.7 \pm 8.30^{\mathrm{a}, \mathrm{b}}$ & $4.62 \pm 1.76^{\mathrm{a}, \mathrm{b}, \mathrm{c}}$ & $68.2 \pm 19.2^{\mathrm{b}}$ & $9.87 \pm 3.84^{\mathrm{a}, \mathrm{b}}$ & $0.25 \pm 0.07^{\mathrm{b}}$ & $35.8 \pm 7.09^{\mathrm{b}}$ & $0.26 \pm 0.14^{\mathrm{a}, \mathrm{b}}$ \\
\hline TEL & 52.3 & 15.9 & 124 & 7.24 & 0.68 & 30.2 & 0.13 \\
\hline ERL & 81.0 & 20.9 & 150 & 8.20 & 1.20 & 46.7 & 0.15 \\
\hline PEL & 160 & 42.8 & 271 & 41.6 & 4.21 & 112 & 0.70 \\
\hline ERM & 370 & 51.6 & 410 & 70 & 9.60 & 218 & 0.71 \\
\hline
\end{tabular}

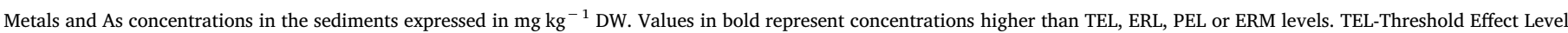

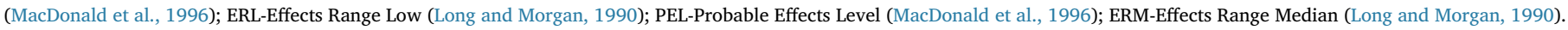
Significant differences $(p<0.05)$ in sediments contamination among areas are represented with distinct letters (a-c).

(Fig. 3B).

The PROT content was generally lower in clams with the lowest metal and As concentration (areas A, C, D), compared to those with high concentrations (areas E, F), with significant statistical differences between the lowest (A) and the highest (B) values (Fig. 3C). However, clams from area B showed the highest PROT content despite the low metal and As concentration.

LPO and GSHt results are showed in Fig. 4A and B respectively.

The LPO was higher in clams from area E, an area characterized by high contaminated clams, and lower in the clams from area A (low contaminated clams), but no significant differences were observed in the LPO levels among clams from different areas (Fig. 4A).

GSHt values were higher in clams from areas B and E (the latter characterized by high contaminated clams), and lower in the clams collected from area A (low contaminated clams), but no significance differences were observed among areas (Fig. 4B).

The activity of the enzymes SOD, CAT, and GSTs are shown in Fig. 5A-C, respectively. The results obtained showed higher SOD activity in areas $\mathrm{B}, \mathrm{C}$ and $\mathrm{D}$ when compared with areas $\mathrm{A}, \mathrm{E}$ and $\mathrm{F}$, but significant differences were found only between area $\mathrm{C}$ and area $\mathrm{F}$ (Fig. 5A). CAT activity was higher in areas A and D, and lower in the area $\mathrm{B}$, but no significant differences were observed among areas (Fig. 5B). Again, the CAT activity did not follow the contamination pattern observed in clams. The GSTs activity was higher in clams from areas $\mathrm{E}$ and $\mathrm{F}$, those with higher metals and As concentrations in clams, with significant differences comparing the area $\mathrm{E}$ with areas B and C, which are characterized by low contaminated clams (Fig. 5C).

MTs synthesis was higher in clams from areas B, C and E (Fig. 6) and significant differences comparing area $\mathrm{C}$ with areas $\mathrm{A}, \mathrm{D}$ and $\mathrm{F}$, where the lowest MTs values were observed.

\subsection{Pearson correlations and multivariate analysis on biological responses to metal and As exposure}

The Pearson correlations showed that the fines content was significantly related to TOM content $(\mathrm{R}=0.98 p<0.01)$, to total metals and As concentration in sediments $(\mathrm{R}=0.83 p<0.05)$ and to $\mathrm{Ni}$ $(\mathrm{R}=0.93 p<0.01)$ and $\mathrm{Cd}(\mathrm{R}=0.82 p<0.05)$ concentrations in sediments.

The element bioaccumulation in clams was not correlated to the metals and As concentrations in the sediments, both considering the total metals and As concentration and those of each element $(\mathrm{R}<0.20$ $p<0.05$ ).

Pearson correlations were not significant among metals and As concentrations in clams and physiological and biochemical parameters, except for: i) Zn bioaccumulation in clams and GLY content ( $\mathrm{R}=0.83$ $p<0.05)$, ii) As bioaccumulation in clams and SOD activity $(\mathrm{R}=0.82$ $p<0.05)$, iii) $\mathrm{Hg}$ bioaccumulation in clams and LPO $(\mathrm{R}=0.82)$ and MTs $(\mathrm{R}=0.85)$ levels $(p<0.05)$. Moreover, significant correlations were identified between GLY content and GSTs activity $(\mathrm{R}=0.93$ $p<0.01$ ), SOD and GSTs activities ( $\mathrm{R}=0.83 p<0.05$ ).

Moreover, the PCA analysis based on clams' contamination (total and single metal and As content) with imposed vectors of physiological and biochemical responses is shown in Fig. 7. The first two components explained the $67.1 \%$ of the total variance: the principal component (Axis 1) accounted for $39.4 \%$ of the total variability and is associated to a gradient that distinguished areas A, B (characterized by low contaminated clams) from areas C, D (with medium contaminated clams) and areas E, F (characterized by high contaminated clams). Biological condition vectors indicated that areas $\mathrm{E}$ and $\mathrm{F}$ are characterized by clams with higher LPO levels ( $L P O)$, GLY content (GLY) and MTs (MT) content, GSTs activity (GSTs) and higher C.I. (C.I.), positively correlated to both single and total metals and As content in clams.

\section{Discussion}

To our knowledge, this is the very first study investigating the metals and As concentrations in the Manila clam population from the Tagus estuary, relating the physiological and biochemical responses to the environmental contamination and clams bioaccumulation levels.

The results obtained for sediment contamination showed that, among the six investigated areas, B and E, respectively outer and inner

Table 3

Metals and As content in the clams of the Tagus estuary.

\begin{tabular}{|c|c|c|c|c|c|c|c|}
\hline Area & $\mathrm{Cr}$ & $\mathrm{Ni}$ & $\mathrm{Zn}$ & As & $\mathrm{Cd}$ & $\mathrm{Pb}$ & $\mathrm{Hg}$ \\
\hline A & $2.25 \pm 0.64^{\mathrm{a}}$ & $1.89 \pm 1.08^{\mathrm{a}, \mathrm{b}}$ & $14.2 \pm 4.23^{\mathrm{a}}$ & $2.42 \pm 0.67^{\mathrm{a}}$ & $0.08 \pm 0.02^{\mathrm{a}}$ & $0.58 \pm 0.24^{\mathrm{b}}$ & $0.03 \pm 0.01^{\mathrm{a}}$ \\
\hline B & $2.00 \pm 0.39^{a}$ & $1.25 \pm 0.29^{\mathrm{a}}$ & $15.0 \pm 5.80^{\mathrm{a}}$ & $3.31 \pm 0.70^{\mathrm{b}, \mathrm{c}}$ & $0.07 \pm 0.02^{\mathrm{a}}$ & $0.49 \pm 0.06^{\mathrm{a}, \mathrm{b}}$ & $0.02 \pm 0.01^{\mathrm{a}}$ \\
\hline C & $6.38 \pm 3.17^{\mathrm{b}}$ & $2.35 \pm 0.40^{\mathrm{b}}$ & $18.1 \pm 5.16^{\mathrm{a}, \mathrm{b}}$ & $2.53 \pm 0.74^{\mathrm{a}, \mathrm{b}}$ & $0.06 \pm 0.00^{\mathrm{a}}$ & $2.78 \pm 2.74^{\mathrm{a}, \mathrm{b}, \mathrm{c}}$ & $0.09 \pm 0.09^{\mathrm{b}}$ \\
\hline D & $2.37 \pm 0.59^{\mathrm{a}}$ & $1.32 \pm 0.24^{\mathrm{a}}$ & $25.4 \pm 8.80^{\mathrm{b}, \mathrm{c}}$ & $3.42 \pm 0.79^{\mathrm{b}, \mathrm{c}}$ & $0.10 \pm 0.03^{\mathrm{a}}$ & $1.73 \pm 0.78^{\mathrm{c}}$ & $0.06 \pm 0.02^{\mathrm{b}}$ \\
\hline $\mathrm{E}$ & $3.20 \pm 1.58^{\mathrm{a}, \mathrm{b}}$ & $1.36 \pm 0.27^{\mathrm{a}}$ & $30.1 \pm 9.72^{\mathrm{c}}$ & $4.79 \pm 1.48^{\mathrm{c}}$ & $0.08 \pm 0.02^{\mathrm{a}}$ & $1.52 \pm 1.32^{\mathrm{c}}$ & $0.13 \pm 0.13^{\mathrm{b}}$ \\
\hline $\mathrm{F}$ & $5.60 \pm 2.46^{\mathrm{b}}$ & $2.58 \pm 0.89^{\mathrm{b}}$ & $24.8 \pm 3.92^{\mathrm{b}, \mathrm{c}}$ & $21.8 \pm 6.50^{\mathrm{a}, \mathrm{b}, \mathrm{c}}$ & $0.08 \pm 0.03^{\mathrm{a}}$ & $0.45 \pm 0.09^{\mathrm{a}}$ & $0.03 \pm 0.01^{\mathrm{a}}$ \\
\hline
\end{tabular}

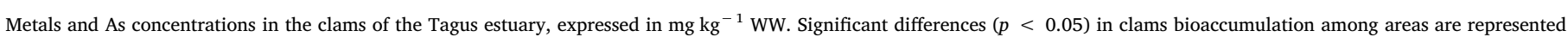
with distinct letters $(\mathrm{a}-\mathrm{c})$. 
Table 4

Biota-Sediment Accumulation Factor (BSAF).

\begin{tabular}{|c|c|c|c|c|c|c|c|c|}
\hline Area & $\mathrm{Cr}$ & $\mathrm{Ni}$ & $\mathrm{Zn}$ & As & $\mathrm{Cd}$ & $\mathrm{Pb}$ & $\mathrm{Hg}$ & BSAF total \\
\hline A & $1.28-4.11^{\mathrm{a}, \mathrm{b}}$ & $2.55-20.2^{\mathrm{a}, \mathrm{b}}$ & $3.03-6.90^{\mathrm{a}, \mathrm{b}}$ & $3.25-9.55^{\mathrm{a}, \mathrm{b}}$ & $8.43-22.7^{b}$ & $0.30-0.70^{\mathrm{b}}$ & $2.09-8.07^{\mathrm{a}, \mathrm{b}, \mathrm{c}}$ & $2.41-5.73^{\mathrm{a}}$ \\
\hline B & $0.64-1.72^{\mathrm{a}}$ & $1.51-3.13^{\mathrm{a}}$ & $0.73-1.56^{\mathrm{a}}$ & $0.61-2.40^{\mathrm{a}}$ & $0.47-2.51^{\mathrm{a}}$ & $0.02-0.11^{\mathrm{a}}$ & $0.21-0.61^{\mathrm{a}}$ & $0.45-1.20^{\mathrm{a}}$ \\
\hline $\mathrm{C}$ & $3.91-7.99^{\mathrm{b}}$ & $5.92-7.27^{\mathrm{b}}$ & $2.65-5.20^{\mathrm{a}, \mathrm{b}}$ & $3.21-5.51^{\mathrm{b}}$ & $5.53-7.78^{\mathrm{b}}$ & $0.71-2.67^{\mathrm{a}, \mathrm{b}}$ & $5.43-7.30^{c}$ & $2.70-4.74^{\mathrm{a}}$ \\
\hline D & $1.42-2.59^{\mathrm{a}, \mathrm{b}}$ & $3.39-8.48^{\mathrm{a}, \mathrm{b}}$ & $1.84-4.59^{\mathrm{a}, \mathrm{b}}$ & $1.44-3.12^{\mathrm{a}, \mathrm{b}}$ & $2.60-7.28^{\mathrm{a}, \mathrm{b}}$ & $0.26-0.46^{\mathrm{b}}$ & $0.26-0.87^{\mathrm{a}}$ & $1.28-2.60^{\mathrm{a}}$ \\
\hline $\mathrm{E}$ & $0.36-1.20^{\mathrm{a}}$ & $1.48-2.46^{\mathrm{a}}$ & $1.50-2.85^{\mathrm{a}, \mathrm{b}}$ & $1.50-3.38^{\mathrm{a}, \mathrm{b}}$ & $0.91-2.73^{\mathrm{a}}$ & $0.10-0.34^{\mathrm{a}, \mathrm{b}}$ & $1.60-2.43^{\mathrm{b}}$ & $0.98-2.03^{\mathrm{a}}$ \\
\hline $\mathrm{F}$ & $1.32-6.45^{\mathrm{a}, \mathrm{b}}$ & $3.05-10.2^{\mathrm{a}, \mathrm{b}}$ & $2.53-4.33^{\mathrm{b}}$ & $3.52-69.8^{\mathrm{a}, \mathrm{b}}$ & $1.95-3.87^{\mathrm{a}}$ & $0.08-0.13^{\mathrm{a}}$ & $0.69-2.07^{\mathrm{a}, \mathrm{b}}$ & $1.83-7.20^{\mathrm{a}}$ \\
\hline
\end{tabular}

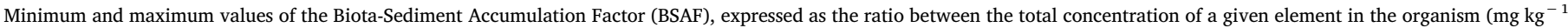

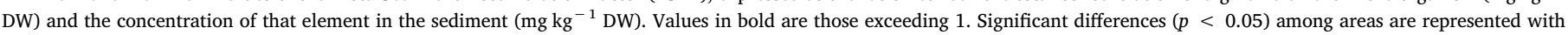
distinct letters $(\mathrm{a}-\mathrm{c})$.

Table 5

Maximum permissible limits (ML) and PTWI (provisional tolerable week intake)

\begin{tabular}{|c|c|c|c|c|c|c|c|}
\hline & & $\mathrm{Cr}$ & $\mathrm{Ni}$ & As & $\mathrm{Cd}$ & $\mathrm{Pb}$ & $\mathrm{Hg}$ \\
\hline \multirow[t]{3}{*}{ ML (mg kg $\left.{ }^{-1} \mathrm{WW}\right)$} & EFSA & & & & 1.00 & 1.50 & 0.50 \\
\hline & USFDA & 13.0 & 80.0 & 86.0 & 4.00 & 1.70 & 1.00 \\
\hline & FSANZ & & & 1.00 & 2.00 & 2.00 & 0.50 \\
\hline PTWI (mg kg ${ }^{-1}$ & JECFA & & 0.035 & 0.015 & 0.007 & 0.025 & 0.005 \\
\hline WW) & FSANZ & & & 0.015 & 0.007 & 0.025 & 0.005 \\
\hline \multicolumn{8}{|c|}{$\begin{array}{l}\text { Amount of clams consumed per } \\
\text { week to exceed PTWI (kg) }\end{array}$} \\
\hline Area A & & & 1.29 & 0.43 & 6.42 & 3.00 & 11.0 \\
\hline Area B & & & 1.96 & 0.32 & 7.42 & 3.54 & 14.0 \\
\hline Area $\mathrm{C}$ & & & 1.04 & 0.41 & 7.88 & 0.63 & 3.70 \\
\hline Area D & & & 1.86 & 0.31 & 4.85 & 1.01 & 6.33 \\
\hline Area E & & & 1.80 & 0.22 & 6.13 & 1.15 & 2.70 \\
\hline Area $\mathrm{F}$ & & & 0.95 & 0.05 & 6.20 & 3.86 & 11.2 \\
\hline
\end{tabular}

Maximum permissible limits (ML) defined by international organizations: EFSA, European Food Safe Authority; USFDA, United States Food and Drug Administration; FSANZ, Food Standards Australia and New Zealand; JECFA, Joint FAO/WHO Expert Committee on Food Additives. PTWI (provisional tolerable week intake) and amount of clams that a $70 \mathrm{~kg}$ adult needs to consume to exceed PTWI for each element: values in bold represent the areas where a higher risk occurs for clams consumption. FSANZ maximum limits (ML) and PTWI values by JECFA and FSANZ for As are referred to inorganic As.

Barreiro Bay, are the most contaminated in terms of metals and As. The lowest contamination values were observed in areas A (Samouco) and C (Airbase). These data confirm the previous mapping on elements distribution in the Tagus estuary (Chainho et al., 2014), since the southern branch of the estuary was impacted by the metallurgic, siderurgic and chemical industries (Vale, 1990). For all elements, values were comparable to those previously described in the Tagus estuary (Mil-Homens et al., 2014), although lower values were herein observed for $\mathrm{Cr}$ and $\mathrm{Ni}$. The most abundant elements herein detected were $\mathrm{Zn}$ and $\mathrm{Pb}$, as already described by Vinagre et al. (2008) in the salt marshes and by Vale et al. (2008) in the superficial sediments of the estuary. Moreover, the present study showed that this estuarine ecosystem presented metals and As concentrations that exceeded reference values: namely $\mathrm{As}, \mathrm{Pb}$ and Hg exceeding TEL (MacDonald et al., 1996) and/or ERL (Long and Morgan, 1990) and Hg values also exceeding PEL and ERM levels (area D), which should not be neglected due to the high toxicity of these elements.

Metals and As concentrations in the sediments are generally higher in the Tagus estuary when compared to those measured in other Portuguese systems where the Manila clam is currently exploited, such as the Ria de Aveiro lagoon and Óbidos lagoon, except for $\mathrm{Hg}$ in a restricted area of Ria de Aveiro (Freitas et al., 2014; Velez et al., 2015a,c) and for $\mathrm{Cr}$ and Ni in Óbidos lagoon (Velez et al., 2015b).

When compared to Atlantic and Mediterranean ecosystems hosting the Manila clam exploitation, values measured in sediments from the Tagus estuary for $\mathrm{Cr}, \mathrm{Ni}, \mathrm{Zn}$ and $\mathrm{Cd}$ are lower than those observed in highly human-impacted environments, like the Venice and the Po River Delta lagoons located in the Northern Adriatic Sea (Moschino et al.,
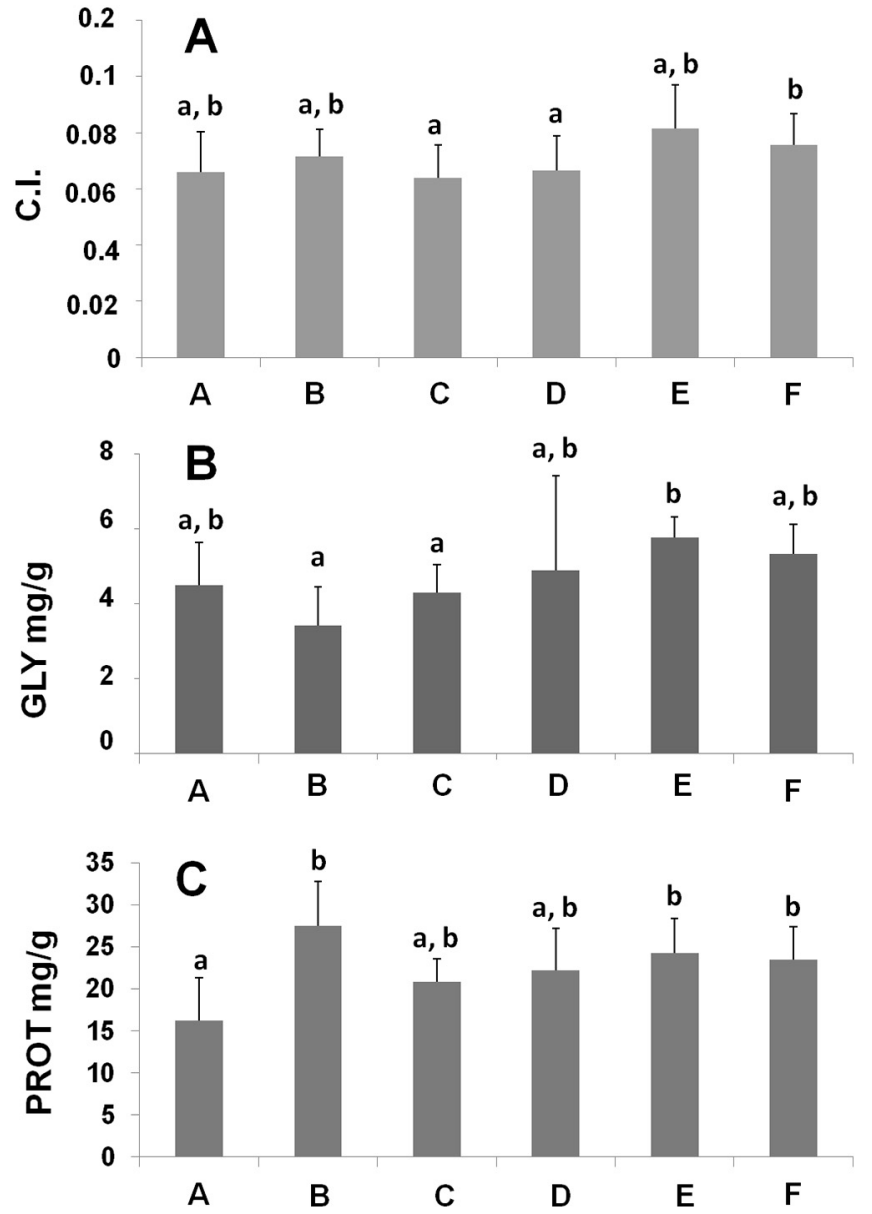

Fig. 3. Condition index, glycogen and proteins content. Condition index - C.I. (A), glycogen content - GLY (B) and protein content - PROT (C) for each analyzed area of the Tagus estuary. Significant differences $(p<0.05)$ among areas are represented with distinct letters $(\mathrm{a}-\mathrm{b})$. Data from the different areas are presented following the bioaccumulation gradient in clams.

2012; Baccarani, 2014). Hg contamination is higher in the Industrial channels of the Venice lagoon (Moschino et al., 2012), although As and $\mathrm{Pb}$ contents are higher in the sediments of the Tagus estuary, especially in areas B and E. Results herein reported from the Tagus estuary showed that the highest contaminated sediments were observed in the areas characterized by higher fines and TOM content. It is known that sediment grain size and organic matter play an important role in metalparticles binding, since elements mostly interact with fine-grained particles surface (Luoma, 1990) and have great affinity for organic matter (Argese et al., 1992). Organic matter along with oxides/hydroxides of $\mathrm{Fe}$ and $\mathrm{Mn}$ can form flocs with clay particles, depositing themselves in a celluloid form on these aggregates (Argese et al., 1992), which helps to stabilize the majority of elements in the sediments 

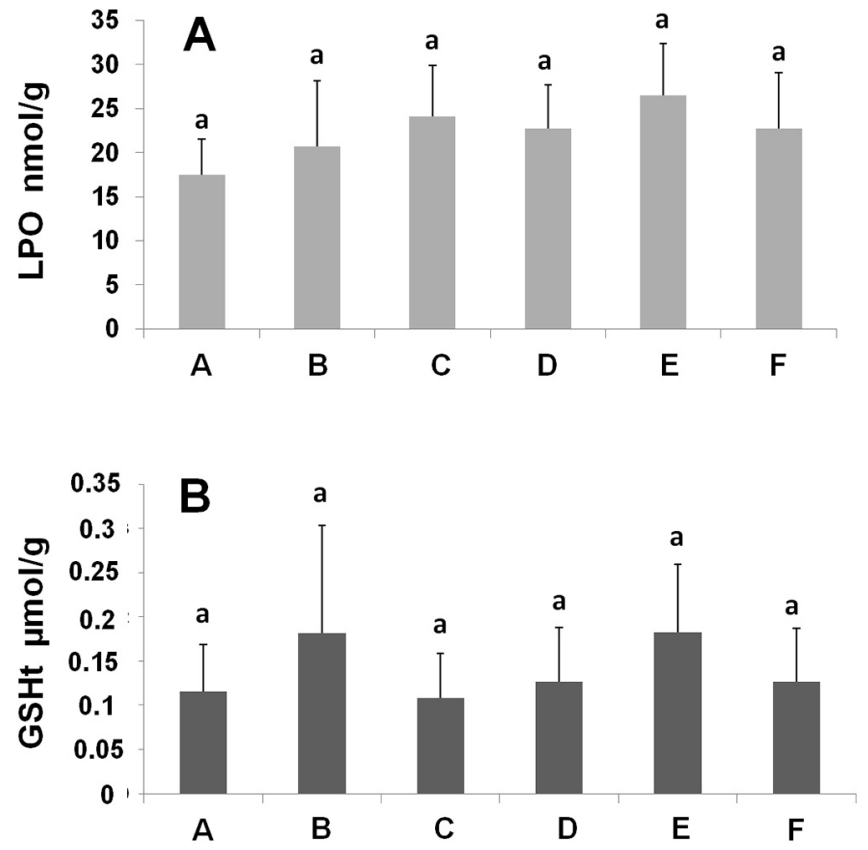

Fig. 4. Lipid peroxidation and total glutathione content. Lipid peroxidation levels - LPO (A) and total glutathione content - GSHt (B) for each analyzed area of the Tagus estuary. No significant differences were observed among areas, as they are represented with the same letter (a). Data from the different areas are presented following the bioaccumulation gradient in clams.

\section{(Burton, 1976).}

Concerning the results of clams' contamination, the highest values for the total metals and As concentration in clams were measured in samples from areas E and F, respectively inner Barreiro Bay and inner Montijo Bay, whilst the lowest values were obtained in clams from areas A (Samouco) and B (Outer Barreiro Bay). These results indicated the absence of a direct correlation among metals and As concentrations in the sediments and in the clams. Also Moschino et al. (2012) and Velez et al. (2015a) demonstrated that the contamination values found in clams were not proportional to the metals and As concentrations measured in the sediments. Although both sediments and clams collected in area $\mathrm{E}$ presented high contamination, clams from the most contaminated area (B) showed lower bioaccumulation values. On the opposite, clams from low or moderated contaminated area, like area F, showed the highest bioaccumulation values. The same results were observed for BSAF values, since higher BSAF values were observed in clams from the least contaminated areas, as previously described for the Manila clam (Moschino et al., 2012; Velez et al., 2015a,b). These results could be explained by the occurrence of different chemical forms of elements in the sediments, depending on sediment granulometric composition, $\mathrm{pH}$ values and oxidative conditions (Argese and Bettiol, 2001). Each of these forms exhibits a different bioavailability and a different potential for remobilization, consequently influencing the bioaccumulation of the different elements in the clams (Argese and Bettiol, 2001).

Manila clam bioaccumulation and BSAF values for metals and As were higher in Tagus than in other Portuguese environments, as the Ria de Aveiro (Velez et al., 2015a) and the Óbidos lagoons (Velez et al., 2015b). Moreover, bioaccumulation values were higher in the Tagus estuary than in Northern Adriatic Sea coastal lagoons, except for $\mathrm{Hg}, \mathrm{Ni}$ and $\mathrm{Zn}$. Additionally, BSAF values were also higher in the Tagus estuary than in the mentioned systems, except for Hg (Baccarani, 2014).

The contamination levels in clams herein detected emphasize the need for a special concern in the consumption of clams from the Tagus estuary, due to the $\mathrm{Pb}$ content in clams from area $\mathrm{C}$, and As severe bioaccumulation in clams from area F. According to the National Status
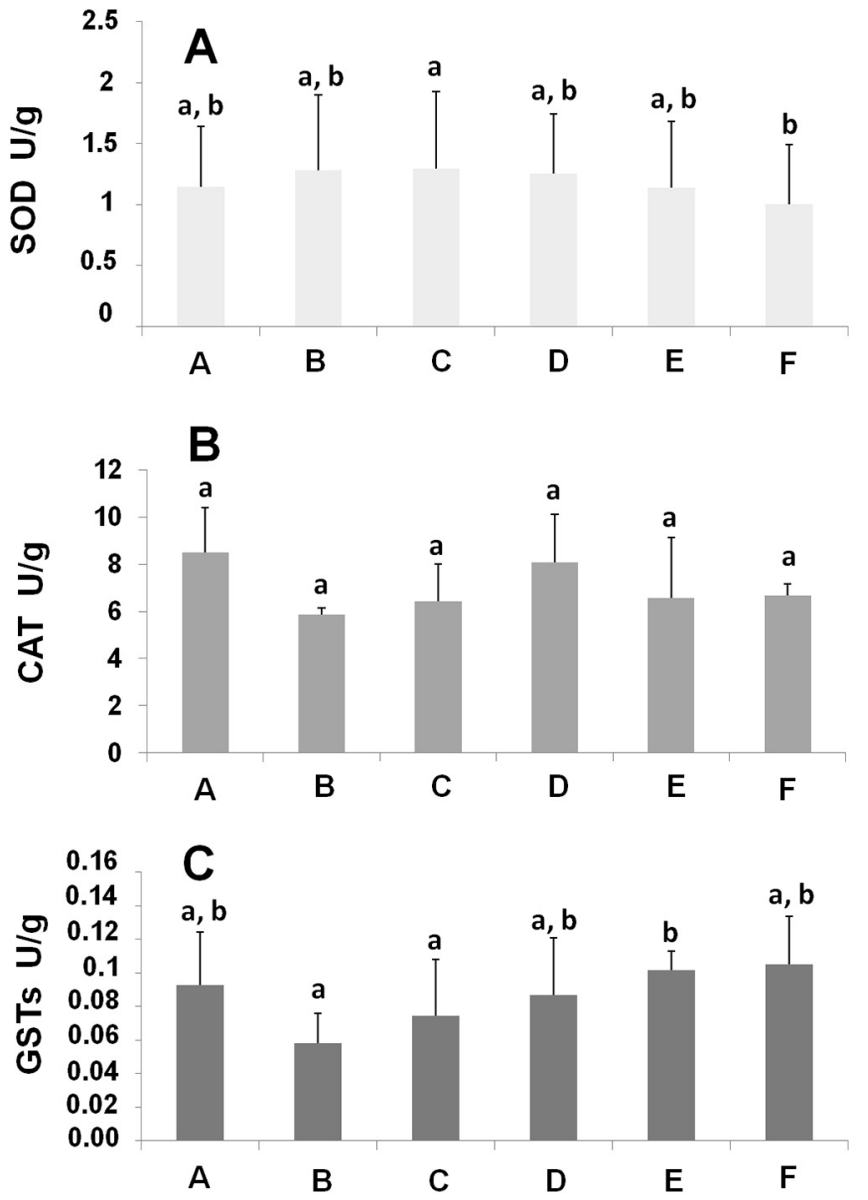

Fig. 5. Superoxide dismutase, catalase and glutathione $S$-transferase. Superoxide dismutase activity - SOD (A); catalase activity - CAT (B); glutathione $S$-transferases activity - GSTs (C) for each analyzed area of the Tagus estuary. Significant differences $(p<0.05)$ among areas are represented with distinct letters (a-b). Data from the different areas are presented following the bioaccumulation gradient in clams.

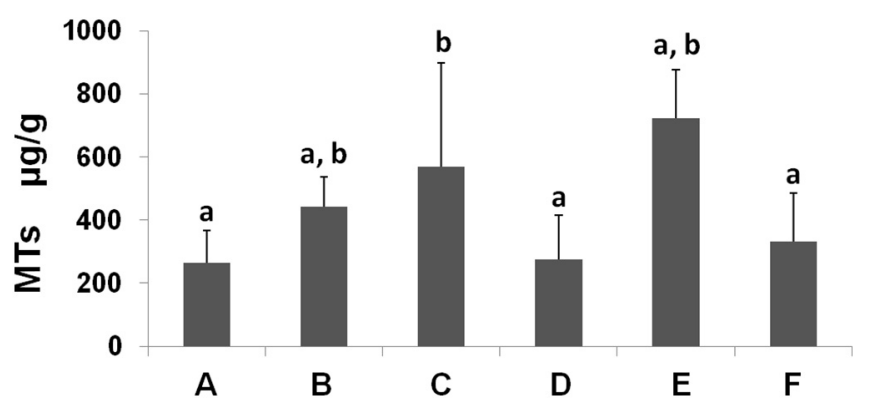

Fig. 6. Metallothioneins (MTs) content. Metallothioneins (MTs) content for each analyzed area of the Tagus estuary. Significant differences $(p<0.05)$ among areas are represented with distinct letters (a-b). Data from the different areas are presented following the bioaccumulation gradient in clams.

and Trends (NST) Mussel Watch Project, mussel contamination is considered 'high' when total As levels are above $14.5 \mathrm{mg} \mathrm{kg}^{-1}$ dry weight (approx. $2.15 \mathrm{mg} \mathrm{kg}^{-1}$ wet weight) (Valette-Silver et al., 1999). In our data, all the analyzed areas presented higher values, up to $21.8 \mathrm{mg} \mathrm{kg}^{-1}$ wet weight in area F. Moreover, limits established by international organizations also rise some concerns, with As concentrations exceeding the FSANZ standard values in all the investigated areas, and $\mathrm{Pb}$ concentrations exceeding the limits established by EFSA in three of the six investigated areas. These findings are also corroborated by the PTWI calculations, indicating high risks for human consumption concerning $\mathrm{Pb}$ in area $\mathrm{C}$; regarding $\mathrm{As}$ in all the investigated 


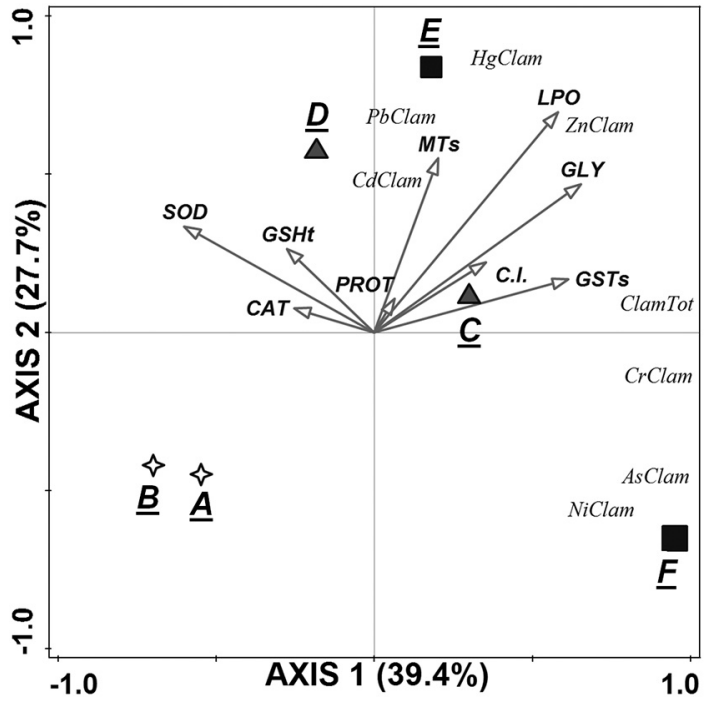

Fig. 7. PCA analysis. Multivariate PCA analysis of physiological and biochemical status of the Manila clam, in response to metals and As accumulation. Star symbols represent areas $\underline{A}, \underline{B}$ (low contaminated clams), triangles represent areas $\underline{C}, \underline{D}$ (medium contaminated clams), squares represent areas $E, F$ (high contaminated clams). Italics represent data distribution on clam contamination for both total (ClamTot) and single metals and As content (CdClam, PbClam, HgClam, ZnClam, CrClam, AsClam, NiClam). Superimposed physiological and biochemical vectors are indicated in bold italics: condition index (C.I.), glycogen ( $G L Y$ ), superoxide dismutase (SOD), catalase (CAT), total glutathione (GSHt) and glutathione $S$-transferase (GSTS), total protein content (PROT), LPO levels (LPO) and metallothioneins content (MTs).

areas, particularly F; and $\mathrm{Ni}$ also represents a dangerous element. In all these cases, $<1 \mathrm{~kg}$ FW of clams consumed per week is sufficient to exceed the PTWI, posing a serious threat for consumers' health.

It must be stated that the results herein presented are referred to the total As content in clams, whilst JECFA and FSANZ limits and PTWI are established only for inorganic As. As is mainly bioaccumulated in seafood as non-toxic organic forms, whilst toxic inorganic forms occur in a small percentage (JECFA, 2011). However, analytical constrains actually limit the achievement of a reliable inorganic As quantification in seafood, especially due to the lack of certified reference material (JECFA, 2011). It must be stated that risks for human consumption, especially due to total As bioaccumulation, have been demonstrated for all Portuguese systems where the Manila clam has been studied, namely the Ria de Aveiro and the Óbidos lagoons (Velez et al., 2015a,b). These findings reveal that clams' consumption can constitute a health risk, even when they are collected in areas with low contamination in sediments (Velez et al., 2015a). Despite the general statement that organic As in seafood is less toxic for humans, and the possible overestimation of As exposure due to clam consumption, a special emphasis is still required for this metalloid, since clams had higher ability to accumulate high As quantities also from low contaminated areas (Velez et al., 2015b).

Concerning the physiological response of clams to metal and As contamination, there was no clear evidence on negative effects since clams collected in areas characterized by higher metal and As content ( $\mathrm{E}$ and $\mathrm{F}$ ) presented the highest C.I. values. The condition index is considered as a useful parameter to evaluate the general physiological condition of bivalves (Moschino et al., 2012). C.I. values determined for the Manila clams of the Tagus estuary did not indicate a reduction of overall condition due to metals and As content. Velez et al. (2015a) showed that $V$. corrugata had the highest C.I. values at the most contaminated areas, but those authors did not find statistical correlation between species C.I. and sediment contamination or clam bioaccumulation. Matozzo et al. (2012) and Moschino et al. (2012) suggested that the C.I. of $R$. philippinarum collected in the Venice lagoon was strongly influenced by seasonal variability, by multiple biotic and abiotic parameters, but not directly correlated with metals and As content. A similar result was also obtained by Baccarani (2014), who did not find significant differences in the C.I. among clams collected in different contaminated areas of the same lagoon.

The present study also investigated the biochemical responses of the Manila clam in the Tagus estuary. Energy resources are, in general, mainly accumulated as GLY and PROT and subsequently consumed during reproduction or stress conditions in bivalve species (Brown and Luoma, 1999; Moussa et al., 2014). The GLY content was higher in the most contaminated clams, particularly in areas $\mathrm{E}$ and $\mathrm{F}$, presenting a significant correlation with $\mathrm{Zn}$ contamination in clams. On the opposite, the highest PROT content was observed at the least contaminated clams (especially from area B). This result was previously observed in clams collected in the Óbidos lagoon, where total PROT content was significantly higher in $R$. philippinarum specimens with low metal and As content (Velez et al., 2015b).

Experimental assays with $R$. philippinarum showed a GLY reduction when the species was exposed to increasing As and $\mathrm{Hg}$ concentrations (Velez et al., 2016b). However, in a field study Planelló et al. (2015) found similar results to those herein obtained for the Tagus estuary: a significant increase in the GLY content of the invertebrate species Chironomus riparius in contaminated river systems, when compared to low contaminated ones. The GLY increase in contaminated clam is consistent with the hypothesis that organisms may reduce their metabolism to preserve their energy reserves to fight against oxidative stress (Sokolova, 2013).

As for the low PROT content observed in contaminated clams, it must be stated that the links between effects occurring at various intracellular levels can be frequently masked by dynamics affecting mRNA stability, PROT turnover, transcriptional and translational mechanisms, especially concerning studies conducted in the field (Regoli and Giuliani, 2014). Thus, we can hypothesize that the low PROT content observed in contaminated clams could be due to complex processes involved in PROT turnover at various cellular levels depending on other factors apart from metals and As content.

LPO showed higher values in area E, which was characterized by both contaminated clams and sediments. A similar result was obtained by other authors in other field studies (Velez et al., 2014, 2015b,c). Moreover, a significant correlation was found between LPO levels and $\mathrm{Hg}$ contamination in clams. These results suggested that metals and As contamination may conduct to ROS over-production, thus inducing LPO in cellular membranes as observed in other bivalves studies (RamosGomez et al., 2011; Figueira et al., 2012; Gillis et al., 2014; de Oliveira et al., 2016). As a consequence, clams should activate antioxidant responses, both enzymatic, as CAT, SOD and GSTs, and non-enzymatic antioxidant systems, as the GSH/GSSG, to reduce the oxidative damage (Regoli and Giuliani, 2014).

Interestingly, clams from the most contaminated area (E) showed the highest GSHt content. A similar result was previously observed in a field study on a different clam species, V. corrugata in the Ria de Aveiro lagoon (Velez et al., 2014). It is noteworthy to observe that the GSHt values obtained in the Tagus estuary were higher in clams from the areas with the most contaminated sediments, specifically B and E. This means that GSHt results herein observed reflected the sediment contamination, instead of clams' bioaccumulation patterns.

GSTs activity was significantly higher in the most contaminated clams, especially from area E. Similar results were already obtained from other studies on natural bivalve populations (Jena et al., 2009; Fernández et al., 2010). Moreover, a significant correlation was found between As content in clams and SOD activity (see Section 3.3), even if none of these enzymes reflected the contamination gradient in sediments and/or clams of the Tagus estuary. Matozzo et al. (2012) studied the natural populations of $R$. philippinarum from the Venice lagoon and suggested that the reduced antioxidant status of clams could depend on both natural (salinity) and anthropogenic factors capable to affect antioxidant enzymes. Despite the GSHt levels and the GSTs activity 
increase observed, these mechanisms were insufficient to reduce the increase of LPO levels, in absence of a relevant CAT and SOD activity. This scenario was already observed by Velez et al. (2015c) in wild $R$. philippinarum populations of the Ria de Aveiro lagoon, with higher GSTs levels observed in areas with higher $\mathrm{Hg}$ accumulation, but no signals for CAT and SOD response. These authors suggested that the increment of GSTs values in the Manila clam may constitute the unique defense response stimulated against oxidative stress, on the opposite, the antioxidant enzymes activities are reduced. A reduced antioxidant enzyme activity in the clams of the Tagus estuary could also depend on the MTs synthesis. The highest MTs content were observed in clams from area B and especially from area $\mathrm{E}$ (both sediment and clam high contamination). Moreover, the clams from this area also presented the highest $\mathrm{Zn}$ and $\mathrm{Hg}$ contents, and a significant correlation was observed between MTs content and $\mathrm{Hg}$ bioaccumulation in clams (see Section 3.3). A higher MTs content in contaminated bivalves was also observed in field studies conducted on the cockle $C$. edule (Freitas et al., 2012) and the clam $V$. corrugata (Velez et al., 2014), even if contrasting results were obtained for C. glaucum (Velez et al., 2016a) and R. philippinarum. Martín-Díaz et al. (2007) showed a significant induction of MTs in the Manila clam in response to metal contaminated sediments, and Velez et al. (2016b) demonstrated that the Manila clam was able to increase MTs synthesis, to prevent the deleterious effects of intracellular free As and $\mathrm{Hg}$ ions, when experimentally exposed to As and $\mathrm{Hg}$. On the opposite, field studies conducted in the Ria de Aveiro (Velez et al., 2015c) and in the Venice lagoon (Moschino et al., 2012) did not evidence different MTs levels among high and low contaminated areas.

It must be stated that differences among MTs results could be due to the interference of various factors like sex, size, gonadal development, food abundance and other environmental parameters (e.g. temperature and salinity), as suggested by Moschino et al. (2012). These authors showed that MTs synthesis in the Venice lagoon is influenced by gonadal development, reflecting seasonal metallothionein trends. Also Oaten et al. (2017) proved that MTs synthesis in Manila clam can change depending on seasonality. $R$. philippinarum from the Tagus estuary are generally in mature phase of reproduction (phase III) or immediately after gametes release (phase IV) during spring months (Moura et al., in press), however they showed an increased synthesis with respect to clams and sediment metals and As content.

Finally, it must be stated that the results obtained by single physiological and biochemical parameters were also corroborated by multivariate patterns (PCA), considering that metals and As content in clams was associated with higher C.I. values, GLY and MTs content, LPO and GSTs levels, particularly at areas E and F (highest contaminated clams).

The use of Manila clam as a bioindicator for metals and As contamination in transitional environment has been debated, since some authors suggested its possible use (Oaten et al., 2017), whilst others (Moschino et al., 2012), demonstrated a weak responsiveness and sensitivity to anthropogenic pollutants, and a lack of biochemical response in field studies (Velez et al., 2015b). The present work demonstrated that condition index (C.I.), LPO levels, GSTs activity, GLY and MTs content measured in Manila clam from the Tagus estuary might be responding to the stress caused by environmental pollution, thus representing possible useful biomarkers. The contrasting results of Manila clam biochemical responses observed in field studies may depend on the occurrence of many confounding factors in natural environments, which influence these responses.

\section{Conclusions}

The present work provides novel data on the metals and As content from sediments and Manila clam samples of the Tagus estuary. Among the six investigated areas, significant differences were observed both for sediments and clams contamination: the most contaminated sediments were identified in areas B (outer) and E (inner) of the Barreiro Bay. The latter area E and area F (inner of Montijo Bay) showed the highest metals and As content in clams. Moreover, As concentrations in clams in all the investigated areas (particularly $\mathrm{F}$ ) and $\mathrm{Pb}$ concentrations in clams from area C (Airbase) raise serious concerns related to the human consumption, considering the limits established by the International organizations and the PTWI estimations.

The identification of areas of high risk for clams consumption should be seriously considered by the local authorities and fishermen of the Tagus estuary. Up to now, the deficient regulations and the prevalence of unlicensed harvesters have contributed to increase the risks for consumers. The Manila clam harvesting in the Tagus estuary should be better regulated and controlled to ensure its safety for producers, consumers and for the conservation of the estuarine environment.

Finally, this work also enhanced the relevance for Manila clam of physiological parameters, namely condition index (C.I.), and biochemical parameters like glycogen content (GLY), oxidative damage (LPO), biotransformation enzymes (GSTs) and metallothioneins (MTs), as consistent indicators of metals and As accumulation in this species.

Supplementary data to this article can be found online at https:// doi.org/10.1016/j.marpolbul.2017.10.088.

\section{Acknowledgements}

Authors would like to thank J. Ramajal (MARE, Faculty of Sciences, Lisbon University) and Cátia Velez (Department of Biology \& CESAM, University of Aveiro) for their help with samples collection and field activities; Anthony P. Moreira for English editing and an anonymous referee for improving the paper.

\section{Funding}

This work has been supported by CESAM (UID/AMB/50017), FCT/ MEC through national funds, and the co-funding by the FEDER, within the PT2020 Partnership Agreement and Compete 2020.

Stefania Chiesa and Rosa Freitas benefited from Post-Doctoral grants (SFRH/BPD/91923/2012 and SFRH/BPD/92258/2013), Ângela Almeida benefited from a Doctoral grant (SFRH/BD/110218/2015), all given by the National Funds through the Portuguese Science Foundation (FCT), supported by European Social Fund, "Programa Operacional Capital Humano (POCH)" and European Community.

Paula Chainho was supported by project PEst-OE/MAR/UI0199/ 2014.

\section{References}

Anderson, M.J., Gorley, R.N., Clarke, K.R., 2008. PERMANOVA for PRIMER: Guide to Software and Statistical Methods. University of Auckland and PRIMER-E, Plymouth. Argese, E., Bettiol, C., 2001. Heavy metal partitioning in sediments from the Lagoon of Venice (Italy). Toxicol. Environ. Chem. 79, 157-170.

Argese, E., Cogoni, G., Zaggia, L., Zonta, R., Pini, R., 1992. Study on redox state and grain size of sediments in a mud flat of the Venice Lagoon. Environ. Geol. Water Sci. 20, $35-42$.

Baccarani, G., 2014. Identification and Validation of Environmental, Physiological and Molecular Markers for Safety and Management of Fishery Resources in Venice Lagoon. (Ph.D. thesis in Environmental Sciences, University of Venice "Cà Foscari", Venice, Italy, $221 \mathrm{pp})$.

Beauchamp, C., Fridovich, I., 1971. Superoxide dismutase: improved assays and an assay applicable to acrylamide gels. Anal. Biochem. 44, 276-287.

Boscolo Brusà, R., Cacciatore, F., Ponis, E., Molin, E., Delaney, E., 2013. Clam culture in the Venice lagoon: stock assessment of Manila clam (Venerupis philippinarum) populations at a nursery site and management proposals to increase clam farming sustainability. Aquat. Living Resour. 26, 1-10.

Brown, C.L., Luoma, S.N., 1999. Metal Trends and Effects in Potamocorbula amurensis in North San Francisco Bay. U.S. Geological Survey, Menlo Park, California.

Buege, J.A., Aust, S.D., 1978. Microsomal lipid peroxidation methods. Enzymology 52, 302-310.

Burton, J.D., 1976. Basic properties and processes in estuarine chemistry. In: Burton, J.D., Liss, P.S. (Eds.), Estuarine Chemistry. Academic Press, London.

Byers, C., Mills, E.L., Steward, P.L., 1978. A comparison of methods of determining organic carbon in marine sediments with suggestions for a standard method. Hydrobiologia 58, 43-47.

Caçador, I., Vale, C., Catarino, F., 1996. The influence of plants on concentration and 
fractionation of $\mathrm{Zn}, \mathrm{Pb}$, and $\mathrm{Cu}$ in salt marsh sediments (Tagus Estuary, Portugal). J. Aquat. Ecosyst. Health 5, 193-198.

Cajaraville, M.P., Bebianno, M.J., Blasco, J., Porte, C., Sarasquete, C., Viarengo, A., 2000. The use of biomarkers to assess the impact of pollution in coastal environments of the Iberian Peninsula: a practical approach. Sci. Total Environ. 247, 295-311.

Calvário, J., 2001. Characterization of the Tagus estuary macrobenthic communities. Boletim do Museu Municipal do Funchal 6, 313-330.

Cardoso, F.D., Dauner, A.L.L., Martins, C.C., 2016. A critical and comparative appraisal of polycyclic aromatic hydrocarbons in sediments and suspended particulate material from a large South American subtropical estuary. Environ. Pollut. 214, 219-229.

Carvalho, F., 2016. Current status and Impacts of the Population of Manila Clam (Ruditapes philippinarum) Introduced in the Tagus Estuary. (MsC. Thesis on Ecology and Environmental Management. Faculty of Sciences, University of Lisbon, $62 \mathrm{pp}$ ).

Chainho, P., Silva, G., Costa, J.L., Costa, M.J., 2014. The Tagus estuary: problems and opportunities of the new River Basin Management Plans. In: The Tagus: History of an Ignored River. Foundation of the New Water Culture, pp. 145-171 (ISBN: 978-84938966-4-5).

Chainho, P., Fernandes, A., Amorim, A., et al., 2015. Non-indigenous species in Portuguese coastal areas, coastal lagoons, estuaries, and islands. Estuar. Coast. Shelf Sci. http://dx.doi.org/10.1016/j.ecss.2015.06.019.

Chandurvelan, R., Marsden, I.D., Glover, C.N., Gaw, S., 2015. Assessment of a mussel as a metal bioindicator of coastal contamination: relationships between metal bioaccumulation and multiple biomarker responses. Sci. Total Environ. 511, 663-675.

Cheng, Z., Man, Y.B., Nie, X.P., Wong, M.H., 2013. Trophic relationships and health risk assessments of trace metals in the aquaculture pond ecosystem of Pearl River Delta, China. Chemosphere 90, 2142-2148.

Covelli, S., Langone, L., Acquavita, A., Piani, R., Emili, A., 2012. Historical flux of mercury associated with mining and industrial sources in the Marano and Grado Lagoon (northern Adriatic Sea). Estuar. Coast. Shelf Sci. 113, 7-19.

de Oliveira, L.F., Cabral, M.T., Vieira, C.E.D., Antoniazzi, M.H., Risso, W.E., Martinez, C.B.D., 2016. Metals bioaccumulation and biomarkers responses in the Neotropical freshwater clam Anodontites trapesialis: implications for monitoring coal mining areas. Sci. Total Environ. 571, 983-991.

Dean, H.K., 2008. The use of polychaetes (Annelida) as indicator species of marine pollution: a review. Rev. Biol. Trop. 56, 11-38.

Doeglas, D.J., 1968. Grain size indices, classification and environment. Sedimentology 10, 8-82.

Du Laing, G., 2011. Redox metal processes and controls in estuaries. In: Treatise on Estuarine and Coastal Science. Elsevier Inc.. http://dx.doi.org/10.1016/B978-0-12374711-2.00406-X.

Duarte, B., Caçador, I., 2012. Particulate metal distribution in Tagus Estuary (Portugal), during a flood episode. Mar. Pollut. Bull. 64, 2109-2116.

Duarte, B., Silva, G., Costa, J.L., Medeiros, J.P., Azeda, C., Sá, E., Metelo, I., Costa, M.J., Caçador, I., 2014. Heavy metal distribution and partitioning in the vicinity of the discharge areas of Lisbon drainage basins (Tagus Estuary, Portugal). J. Sea Res. 93, $101-111$.

Dubois, M., Gilles, K.A., Hamilton, J.K., Rebers, P.A., Smith, F., 1956. Colorimetric method for determination of sugars and related substances. Anal. Chem. 28, 350-356.

Elliott, M., Quintino, V., 2007. The estuarine quality paradox, environmental homeostasis and the difficulty of detecting anthropogenic stress in naturally stresses areas. Mar. Pollut. Bull. 54, 640-645.

FAO, 2013. FAO Yearbook. Fishery and Aquaculture Statistics 2011. Food and Agriculture Organization of the United Nations, Rome, pp. 76.

Fernández, B., Campillo, J.A., Martínez-Gómez, C., Benedicto, J., 2010. Antioxidant responses in gills of mussel (Mytilus galloprovincialis) as biomarkers of environmental stress along the Spanish Mediterranean coast. Aquat. Toxicol. 99, 86-197.

Figueira, E., Lima, A., Branco, D., Quintino, V., Rodrigues, A.M., Freitas, R., 2011. Health concerns of consuming cockles (Cerastoderma edule L.) from a low contaminated coastal system. Environ. Int. 37, 965-972.

Figueira, E., Cardoso, P., Freitas, R., 2012. Ruditapes decussatus and Ruditapes philippinarum exposed to cadmium: toxicological effects and bioaccumulation patterns. Comp. Biochem. Physiol., Part C: Toxicol. Pharmacol. 156, 80-86.

Freitas, R., Costa, E., Velez, C., Santos, J., Lima, A., Oliveira, C., Rodrigues, A.M., Quintino, V., Figueira, E., 2012. Looking for suitable biomarkers in benthic macroinvertebrates inhabiting coastal areas with low metal contamination: comparison between the bivalve Cerastoderma edule and the Polychaete Diopatra neapolitana. Ecotoxicol. Environ. Saf. 75, 109-118.

Freitas, R., Martins, R., Campino, B., Figueira, E., Soares, A.M.V.M., Montaudouin, X., 2014. Trematode communities in cockles (Cerastoderma edule) of the Ria de Aveiro (Portugal): Influence of inorganic contamination. Mar. Pollut. Bull. 82, 117-126.

Gao, M., Klerks, P.L., Wu, X., Chen, H.X., Xie, L.T., 2016. Metal concentrations in sedi ment and biota of the Huludao Coast in Liaodong Bay and associated human and ecological health risks. Arch. Environ. Contam. Toxicol. 71, 87-96.

Gaspar, M.B., 2010. Distribuição, abundância e estrutura demográfica da amêijoa Japonesa (Ruditapes philippinarum) no Rio Tejo. Relatório do IPIMAR. (6 pp).

Gillis, P.L., Higgins, S.K., Jorge, M.B., 2014. Evidence of oxidative stress in wild freshwater mussels (Lasmigona costata) exposed to urban-derived contaminants. Ecotoxicol. Environ. Saf. 102, 62-69.

Gosling, E., 2003. Bivalve Molluscs: Biology, Ecology and Culture. Fishing News Books, Blackwell Publishing, Oxford.

Habig, W.H., Pabst, M.J., Jakoby, W.B., 1974. Glutathione S-transferases. The first enzymatic step in mercapturic acid formation. J. Biol. Chem. 249, 7130-7139.

Heberer, T., 2002. Occurrence, fate, and removal of pharmaceutical residues in the aquatic environment: a review of recent research data. Toxicol. Lett. 131, 5-17.

Hoffman, D.J., Rattner, B.A., Cairns, Burton J.A., Jr, J., 2002. Handbook of Ecotoxicology, second edition. CRC Press (1302 pp).

JECFA, 2011. Arsenic. In: Evaluation of Certain Contaminants in Food: Seventy-second Report of the Joint FAO/WHO Expert Committee on Food Additives. WHO Technical Report Series N. 959 WHO Press, World Health Organization, Switzerland, pp. 21-37.

Jena, K.B., Verlecar, X.N., Chainy, G.B.N., 2009. Application of oxidative stress indices in natural populations of Perna viridis as biomarker of environmental pollution. Mar. Pollut. Bull. 58, 107-113.

Johansson, L.H., Borg, L.A.H., 1988. A spectrophotometric method for determination of catalase activity in small tissue samples. Anal. Biochem. 174, 331-336.

Laemmli, U.K., 1970. Cleavage of structural proteins during the assembly of the head of bacteriophage T4. Nature 227, 680-685.

Larsonneur, C., 1977. La cartographie des depots meubles sur le plateau continental francais: methode mise au point et utilisen Manche. J. Rech. Oceanogr. 2, 33-39.

Lei, P., Zhang, H., Shan, B.Q., Lu, S., Tang, W., 2016. Heavy metals in estuarine surface sediments of the Hai River Basin, variation characteristics, chemical speciation and ecological risk. Environ. Sci. Pollut. Res. 23, 7869-7879.

Long, E.R., Morgan, L.G., 1990. The Potential for Biological Effects of sediment-sorbed Contaminants Tested in the National Status and Trends program. NOAA Technical Memorandum NOS OMA 52, Seattle, WA (175 pp).

Luoma, S.N., 1990. Process affecting metal concentration in estuarine and costal marine sediments. In: Furness, R.W., Rainbow, P.S. (Eds.), Heavy Metal in Marine Environments. CRC Press, Boca Raton FL, pp. 51-66.

MacDonald, D.D., Carr, S., Calder, F., Long, E., Ingersoll, C., 1996. Development and evaluation of sediment quality guidelines for Florida coastal waters. Ecotoxicology 5, 253-278.

Martín-Díaz, M.L., Blasco, J., Sales, D., DelValls, T.A., 2007. Bio-markers study for sediment quality assessment in Spanish ports using the crab Carcinus maenas and the clam Ruditapes philippinarum. Arch. Environ. Contam. Toxicol. 53, 66-76.

Matozzo, V., Binelli, A., Parolini, M., Previato, M., Masiero, L., Finos, L., Bressan, M., Marin, M.G., 2012. Biomarker responses in the clam Ruditapes philippinarum and contamination levels in sediments from seaward and landward sites in the Lagoon of Venice. Ecol. Indic. 19, 191-205.

Mil-Homens, M., Vale, C., Raimundo, J., Pereira, P., Brito, P., Caetano, M., 2014. Major factors influencing the elemental composition of surface estuarine sediments: the case of 15 estuaries in Portugal. Mar. Pollut. Bull. 84, 135-146.

Mitchell, S., West, J., Arundale, A., et al., 1999. Dynamics of the turbidity maxima in the upper Humber estuary system, UK. Mar. Pollut. Bull. 37, 190-205.

Monserrat, J.M., Martínez, P.E., Geracitano, L.A., Amado, L.L., Martins, C.M.G., Pinho, G.L.L., Chaves, I.S., Ferreira-Cravo, M., Ventura-Lima, J., Bianchini, A., 2007. Pollution biomarkers in estuarine animals: critical review and new perspectives. Comp. Biochem. Physiol., Part C: Toxicol. Pharmacol. 146, 221-234.

Moschino, V., Delaney, E., Da Ros, L., 2012. Assessing the significance of Ruditapes philippinarum as a sentinel for sediment pollution: bioaccumulation and biomarker responses. Environ. Pollut. 171, 52-60.

Moura, P., Vasconcelos, P., Pereira, F., Chainho, P., Costa, J., Gaspar, M., 2017. Reproductive cycle of the Manila clam (Ruditapes philippinarum): an intensively harvested invasive species in the Tagus Estuary (Portugal). J. Mar. Biol. Assoc. U.K. http://dx.doi.org/10.1017/S0025315417001382.

Moussa, R.M., ElSalhia, M., Khalifa, A., 2014. Energy storage and allocation of pearl oyster Pinctada radiate (Leach, 1814) in relation to timing of pearl seeding. Int. J. Biol. Sci. 3, 53-66.

Oaten, J.F.P., Hudson, M.D., Jensen, A.C., Williams, I.D., 2017. Seasonal effects to metallothionein responses to metal exposure in a naturalised population of Ruditapes philippinarum in a semi-enclosed estuarine environment. Sci. Total Environ. 575, 1279-1290.

Planelló, R., Servia, M.J., Gómez-Sande, P., Herrero, Ó., Cobo, F., Morcillo, G., 2015. Transcriptional responses, metabolic activity and mouthpart deformities in natural populations of Chironomus riparius larvae exposed to environmental pollutants. Environ. Toxicol. http://dx.doi.org/10.1002/tox.

Ponsero, A., Dabouineau, L., Allain, J., 2009. Modelling of common European cockle Cerastoderma edule fishing grounds aimed at sustainable management of traditional harvesting. Fish. Sci. 75, 839-850.

Pranovi, F., Libralato, S., Raicevich, S., Granzotto, A., Pastres, R., Giovananrdi, O., 2003. Mechanical clam dredging in Venice lagoon: ecosystem effects evaluated with a trophic mass-balance model. Mar. Biol. 143, 393-403.

Pranovi, F., Da Ponte, F., Raicevich, S., Giovanardi, O., 2004. A multidisciplinary study of the immediate effects of mechanical clam-harvesting in the Venice Lagoon. ICES J. Mar. Sci. 1, 43-52.

Quintino, V., Rodrigues, A.M., Gentil, F., 1989. Assessment of macro-zoobenthic communities in the lagoon of Obidos, western of Portugal. Sci. Mar. 53, 645-654.

Rahman, I., Kode, A., Biswas, S.K., 2007. Assay for quantitative determination of glutathione and glutathione disulfide levels using enzymatic recycling method. Nat. Protoc. 1, 3159-3165.

Ramajal, J., Picard, D., Costa, L.J., Carvalho, F.B., Gaspar, M.B., Chainho, P., 2016. Amêijoa Japonesa, uma nova realidade no Estuário do Rio Tejo: pesca e pressão social e impacto socio-económico. Chapter I. In: Cancela da Fonseca, L., Garcia, A.C., Dias Pereira, S., Rodrigues, M.A.C. (Eds.), Entre Rios e Mares: um Património de Ambientes, História e Saberes - Tomo I da Rede BrasPor. UERJ, Lisbon, pp. 17-30.

Ramos-Gomez, J., Coz, A., Viguri, J.R., Luque, A., Martın Diaz, M.L.T., Del Valls, A., 2011. Biomarker responsiveness in different tissues of caged Ruditapes philippinarum and its use within an integrated sediment quality assessment. Environ. Pollut. 159, 1914-1922.

Regoli, F., Giuliani, M.E., 2014. Oxidative pathways of chemical toxicity and oxidative stress biomarkers in marine organisms. Mar. Environ. Res. 93, 106-117.

Robinson, H.W., Hogden, C.G., 1940. The biuret reaction in the determination of serum proteins. J. Biol. Chem. 135, 707-725. 
Ruano, F., Sobral, D.V., 2000. Marine non-indigenous species current situation in Portugal. In: Rodrigues, L., Reino, L., Godinho, L.O., Freitas, H. (Eds.), Proceedings of the 1st Symposium on Non-indigenous Species: Introduction, Causes and Consequences. Liga para a Protecção da Natureza, Lisbon, pp. 58-63.

Santos, I., Diniz, M.S., Carvalho, M.L., Santos, J.P., 2014. Assessment of essential elements and heavy metals content on Mytilus galloprovincialis from river Tagus estuary. Biol. Trace Elem. Res. 159, 233-240.

Sfriso, A., Argese, E., Bettiol, C., Facca, C., 2008. Tapes philippinarum seed exposure to metals in polluted areas of the Venice lagoon. Estuar. Coast. Shelf Sci. 79, 581-590.

Sokolova, I.M., 2013. Energy-limited tolerance to stress as a conceptual framework to integrate the effects of multiple stressors. Integr. Comp. Biol. 1-22.

Vale, C., 1990. Temporal variations of particulate metals in the Tagus River Estuary. Sci. Total Environ. 97, 137-154.

Vale, C., Canário, J., Caetano, M., Lavrado, J., Brito, P., 2008. Estimation of the anthropogenic fraction of elements in surface sediments of the Tagus Estuary (Portugal). Mar. Pollut. Bull. 56, 1353-1376.

Valette-Silver, N.J., Riedel, G.F., Crecelius, E.A., Windom, H., Smith, R.G., Dolvin, S.S, 1999. Elevated arsenic concentrations in bivalves from the southeast coasts of the USA. Mar. Environ. Res. 48, 311-333.

Vazquez-Luis, M., Morato, M., Campillo, J.A., Guitart, C., Deudero, S., 2016. High metal contents in the fan mussel Pinna nobilis in the Balearic Archipelago (western Mediterranean Sea) and a review of concentrations in marine bivalves (Pinnidae). Sci. Mar. 80, 111-122.

Velez, C., Freitas, R., Soares, A.M.V.M., Figueira, E., 2014. Bioaccumulation patterns, element partitioning and biochemical performance of Venerupis corrugate from a low contaminated system. Environ. Toxicol. http://dx.doi.org/10.1002/tox.22070.

Velez, C., Figueira, E., Soares, A.M.V.M., Freitas, R., 2015a. Spatial distribution and bioaccumulation patterns in three clam populations from a low contaminated ecosystem. Estuar. Coast. Shelf Sci. 155, 114-125.

Velez, C., Leandro, S., Figueira, E., Soares, A.M.V.M., Freitas, R., 2015b. Biochemical performance of native and introduced clam species living in sympatry: the role of elements accumulation and partitioning. Mar. Environ. Res. 109, 81-94.

Velez, C., Galvao, P., Longo, R., Malm, O., Soares, A.M.V.M., Figueira, E., Freitas, R., 2015c. Ruditapes philippinarum and Ruditapes decussatus under $\mathrm{Hg}$ environmental contamination. Environ. Sci. Pollut. Res. 22, 11890-11904.

Velez, C., Pires, A., Sampaio, L., Cardoso, P., Moreira, A., Leandro, S., Figueira, E., Soares, A.M.V.M., Freitas, R., 2016a. The use of Cerastoderma glaucum as a sentinel and bioindicator species: take-home message. Ecol. Indic. 62, 228-241.

Velez, C., Freitas, R., Antunes, S.C., Soares, A.M.V.M., Figueira, E., 2016b. Clams sensitivity towards As and Hg: a comprehensive assessment of native and exotic species. Ecotoxicol. Environ. Saf. 125, 43-54.

Vinagre, C., Cabral, H.N., Caçador, I., 2008. Influence of halophytes and metal contamination on salt marsh macro-benthic communities. Estuar. Coast. Shelf Sci. 76, 715-722.

Yang, F., Zhao, L., Yan, X., Wang, Y., 2013. Bioaccumulation of trace elements in Ruditapes philippinarum from China: public health risk assessment implications. Int. J. Environ. Res. Public Health 10, 1392-1405.

Zhao, S., Zhu, L., Li, D., 2015. Microplastic in three urban estuaries, China. Environ. Pollut. 206, 597-604. 